\title{
HET PRINSELIJK HOF TEN WALLE IN GENT: RECENT ONDERZOEK EN NIEUWE INZICHTEN
}

\author{
door Marie Christine Laleman
}

\section{Ter introductie}

Op haar jaarvergadering van 2 december 2000 bood de Maatschappij voor Geschiedenis en Oudheidkunde een voordracht aan over het Gentse Prinsenhof. Aanleiding daartoe waren de resultaten van een projectonderzoek dat in 1998 van start ging. De openbare verkoop, op 2 oktober 1998, van het eigendom Goedertier, gelegen tussen het Prinsenhofplein en de Sanderswal, wekte toen bij heel wat Gentenaren onrust. Wat zou er geschieden met de relicten van het Prinsenhof, die nog in dat bouwblok aanwezig waren? Ze genoten geen bescherming en waren ze dan niet onherroepelijk gedoemd te verdwijnen? De verontruste Gentenaren vonden gehoor bij de Gentse Vereniging voor Stadsarcheologie ${ }^{1}$, die een project opzette met een dubbele doelstelling. Allereerst beoogde men een inventaris van de beschikbare kennis. Wat is er eigenlijk over het Gentse Prinsenhof bekend? Wat bleef er van die vorstelijke residentie over in de stad van vandaag? Tevens zou die nieuwe kennis de basis vormen voor het uitwerken van een meervoudig beschermingsvoorstel: als archeologische site, als historisch areaal en als monumentaal erfgoed. Toen de vermelde vereniging in november 1998 een dergelijk beschermingsvoorstel bij de hogere overheid introduceerde, was enkel de Donkere Poort met de onmiddellijke omgeving wettelijk beschermd ${ }^{2}$. Behalve buurtbewoners en G.V.S.A-mensen sloten diverse specialisten zich

I Gentse Vereniging voor Stadsarcheologie, Vijfwindgatenstraat 2, B9000 Gent. Projectcoördinator was Dirk Laporte, docent architectuurgeschiedenis. Het project kon rekenen op betoelaging van de Stad Gent en werd voorts in belangrijke mate financieel ondersteund door de N.V. Denys, de Rotary Prinsenhof en de VdKbank. We willen deze gelegenheid benutten om allen te danken die zich in de periode 1998-2000 heel intensief hebben ingezet voor het welslagen van het Project Prinsenhof of die daartoe op de een of andere manier hebben bijgedragen.

2 De bescherming als monument van het Sastehuis en de Donkere Poort, en als stadsgezicht van de aansluitende omgeving, dagtekent van 2 februari 1981. Bij besluit van 5 oktober 1993 werden de machinekamer, het ketelhuis, de transmissieriemengang en de vierkante schoorsteen van de voormalige fabriek Van Acker, ten noorden van de Donkere Poort langsheen Bachtenwalle, als monument beschermd en bij besluit van 10 maart 1994 in een beschermd stadsgezicht opgenomen. Zie onder meer: DEMEY, A., e.a., 'Beschermde monumenten, stads- en dorpsgezichten en landschappen', in: DE KEGEL, A., e.a., Monumtenzorg en Cultuurpatrimonium. Jaarverslag van de Provincie Oost-Vlaanderen 1993-1994, Gent, 1995, p. 199-200; PIETERAERENS, M., 'Gent', in: Kultureel Jaarboek Provincie Oost-Vlaanderen 1993, Gent, 1995, p. 173-174. 


\section{MARIE CHRISTINE LALEMAN}

aan bij dit projectonderzoek dat als niet officieel gestructureerd samenwerkingsverband functioneerde. Historici, kunsthistorici, bouwhistorici, architecten, natuurwetenschappers, geografen en archeologen deden nieuw onderzoekswerk en stelden hun professionele expertise ter beschikking van het Project Prinsenhof. De wetenschappelijke werkzaamheden verliepen in nauwe samenwerking met de buurt, wat onder meer tot uiting kwam tijdens de Prinsenhoffeesten van 1999 en 2000. Ook via tentoonstellingen en geleide bezoeken werden de wetenschappelijke bevindingen bekend gemaakt. Zo werden verder de belangrijkste delen van de site op het openbaar domein uitgetekend. De link die aldus tussen gespecialiseerde wetenschappelijke expertise en buurt werd gerealiseerd, ondersteunt een gezamenlijke betrokkenheid bij het erfgoed, in casu zeer broos en bedreigd archeologisch, historisch en monumentaal patrimonium.

De resultaten van het projectonderzoek werden een eerste keer samengevat in een publicatie die door de Gentse Vereniging voor Stadsarcheologie in 2000 werd uitgegeven ${ }^{3}$. Verscheidene deelaspecten werden inmiddels verder uitgewerkt. Dit geldt onder meer voor het archiefonderzoek van historicus Daniel Lievois ${ }^{4}$ over de 16de-eeuw, wat in de Keizer Karel-uitgave van de Maatschappij voor Geschiedenis en Oudheidkunde werd aangeboden. In dezelfde publicatie vindt men een bijdrage van Prof. Dr. Ir. Krista De Jonge ${ }^{5}$ die er het Gentse Hostel de la Motte vergelijkt met de hertogelijke residenties van Brugge en Lille. Dezelfde auteur belichtte ook andere aspecten zoals het

3 LALEMAN, M.C. (dir.), Het prinselijk Hof ten Walle in Gent, (Gentse Vereniging voor Stadsarcheologie), Gent, 2000, $281 \mathrm{pp}$.

4 LIEVOIS, D., 'Het Hof ten Walle in Gent ten tijde van Keizer Karel V', in: Handelingen der Maatschappij voor Geschiedenis en Oudheidkunde, Gent, 2000, nr. 54, p. 135-191.

5 DE JONGE, K., 'Bourgondische residenties in het graafschap Vlaanderen: Rijsel, Brugge en Gent ten tijde van Filips de Goede', in: Handelingen der Maatschappij voor Geschiedenis en Oudheidkunde, Gent, 2000, nr. 54, p. 93-134. 
functioneren van dergelijke vorstelijke en adellijke residenties ${ }^{6}$. In deze bijdrage ligt de klemtoon op een aantal andere aspecten, met name de plaats van de site in de ontwikkeling van Gent, de betekenis van de site in ruimere context en de problemen rond een degelijk erfgoedbeheer van dit Gentse deelgebied.

De voorstellen voor bscherming die de Gentse Vereniging voor Stadsarcheologie in november 1998 aan de hogere overheid overmaakte, werden op het gemeentelijke en provinciale niveau gunstig geadviseerd, maar kenden aanvankelijk geen gevolg. In een bijgestuurde versie werd bij ministerieel besluit van 13 november 2001 de site van het voormalige Prinsenhof, gelegen aan Abrahamstraat, Burgstraat, Simon de Mirabellostraat, Gewad, Pluimstraat, Prinsenhof, Prinsenhofplein, Rabotstraat, Sanderswal, Tinnenpotstraat, Varkensstraat en Zilverhof om zijn historische waarde beschermd als stadsgezicht. Voorts werden volgens hetzelfde besluit een aantal gebouwen en monumentale resten beschermd als monument. Het gaat onder meer om in opstand bewaarde delen van de omheiningsmuur, delen van de kerngebouwen gelegen aan Simon de Mirabellostraat, Prinsenhof en Sanderswal. Ook enkele jongere monumenten die na de verkaveling tot stand gekomen zijn, zoals delen van het klooster van de ongeschoeide karmelieten, de woning van bouwmeester Joachim Frans Colin (ca. 1735-1807) en de woning van Jean Baptiste Bethune (1821-1894) aan het Prinsenhof werden volgens hetzelfde besluit als monument beschermd.

6 DE JONGE, $K$., 'Het paleis op de Coudenberg te Brussel in de vijftiende eeuw. De verdwenen hertogelijke residenties in de Zuidelijke Nederlanden in een nieuw licht geplaatst', in: Belgisch Tijdschrift voor Oudheidkunde en Kunstgeschiedenis, 1991, nr. 60, p. 5-38; DE JONGE, K., 'Le palais de Charles-Quint à Bruxelles. Ses dispositions intérieures aux XVe et XVIe siècles et le cérémorial de Bourgogne', in: GUILLAUME, J. (red.), Architecture et vie sociale. L'organisation des grandes demeures à la fin du Moyen Age et à la Renaissance, (De Architectura), Paris, 1994, p. 119-121; DE JONGE, K., 'De Europese context', in: SMOLARMEYNART, A \& VANRIE, A (red.), Het.paleis te Brussel. Acht eeuwen kunst en geschiedenis, Brussel, 1991, p. 161-171; DE JONGE, K., 'L'environnement des châteaux dans les Pays-Bas méridionaux au XVIe siècle et au début du XVIIe siècle', in: Architecture, jardin, paysage. L'environnement du château et de la villa aux XVe et XVle siècles, Paris, 1999, p. xx-xx; DE JONGE, K., 't Hof van Brabant als symbool van de Spaanse hofhouding in de Lage Landen', in: Bulletin van de Koninklijke Nederlandse Oudheidkundige Bond, Leiden, 1999, jg. 98 nr. 5-6, p. 183-198; DE JONGE, K., 'Hofordnungen als Quellen der Residenzenforschung? Adlige und herzogliche Residenzen in den südlichen Niederlanden in der Burgunderzeit', in: KRUSE, H. \& PARAVICINI, W. (red.), Höfe und Hofordnungen. Ordonnances de l'Hôtel (1200-1600). 5. Symposium der Residenzenkommission der Göttinger Akademie in Zusammenarbeit mit dem Deutschen Historischen Institut Paris. Sigmaringen, 5-8 Oktober 1996, Sigmaringen, 1999, p. 173-218. DE JONGE, K., 'Leven in een hertogeljk paleis. Organisatie van een Bourgondisch paleis', in: LALEMAN, M.C. (dir.), Op. cit., p. 67-71. 


\section{MARIE CHRISTINE LALEMAN}

\section{De Wal}

De Prinsenhofwijk is thans een noordwestelijk deelgebied van Gent zoals de stad zich binnen de prefusiegrenzen aftekende. De vroegste ontwikkeling van dit areaal kan niet worden losgekoppeld van de weinig gunstige topografische ligging 7 . Het ging immers om een deel van een uitgestrekt moerassig gebied, bekend als de Wondelgemmeersen ${ }^{8}$. Dit areaal, in hoofdzaak bepaald door alluvia van diverse Leie-armen en met een hoogte van 5 tot $6 \mathrm{~m}$ boven de zeespiegel, was niet voor bewoning geschikt. Tot op heden zijn er geen aanwijzingen voor hogere zandige opduikingen met voor-middeleeuwse of vroegmiddeleeuwse menselijke aanwezigheid binnen het areaal van het latere Prinsenhof. De oudste gegevens zijn niet ouder dan de 11de-12de eeuw en gaan samen met de inplanting van een adellijk mottekasteel.

Het latere Prinsenhof is ontstaan uit een goed,'bekend als de Wal, le Wal of het Hof ten Walle. In 1231 wordt dit omschreven als een land met wal en voorhof, gelegen tussen het Gravensteen en Wondelgem. Het was toen eigendom van burggraaf Hugo II $(+1232)^{9}$ en zijn echtgenote Oda de Champlitte ${ }^{10}$ en werd omschreven als ...quod mansuram nostram totam, scilicet Wal et Vorhof et terram que dicitur Boengartlant, cum fossis et apendiciis attinentibus, que jacent inter castellum comitis et Wondelghem. Dit adellijke goed kan worden getypeerd als een mottekasteel, wat historicus Hermann Van Duyse reeds in 1898 voorstelde $^{11}$. Het herkennen van middeleeuwse mottekastelen in een

7 Zie onder meer: DE PORRE, A. \& GELAUDE, F., 'Het Hof ten Walle aan de rand van Gent. Het landschap rond Gent', in: LALEMAN, M.C. (dir.), Op. cit., p. 9-12.

8 GYSSELING, M., Gent's vroegste geschiedenis in de spiegel van zijn plaatsnamen, Antwerpen, e.a., 1954, p. 87.

$9 \quad \mathrm{Hij}$ werd bijgezet in de abdijkerk van Onze-Lieve-Vrouw ten Bos in Lokeren. Het monument werd bij de verhuizing van de abdij van Lokeren naar Heusden in 1246-1248 mee overgebracht waar het in 1948 als archeologische vondst werd gerecupereerd. Het behoort thans tot één van de bekende collectiestukken van het Bijlokemuseum. NOWE, H., 'Le gisant de l'abbaye de Nieuwen Bossche à Heusden', in: Revue belge d'archéologie et d'histoire de l'art, Bruxelles, 1952, p. 153-173; DIDIER, R. \& STEYAERT, J., 'De beeldhouwkunst der middeleeuwen', in: Gent, duizend jaar kunst en cultuur, Gent, 1975, deel 1, p. 444-446. Zie ook: GYSSELING, M., 'De leliester van de burggraven van Gent, heren van Heusden', in: Jaarboek De OostOudburg, Gent, 1989, nr. 26, p. 193-195.

10 VAN DER HAEGHEN, V., Het klooster ten Walle en de abdij van den Groenen Briel. Stukken en oorkonden, Gent, 1888, p. I en p. 4-6; BLOCKMANS, F., Het Gentsche stadspatriciaat tot omstreeks 1302, Antwerpen - s' Gravenhage, 1938, p. 402-403; Zie ook VAN LOKEREN, A., 'La Cour du Prince à Gand 1231-1835', in: Messager des sciences historiques, Gand, 1841, p. 36-52.

11 VAN DUYSE, H., 'La Cour du Prince ou "Prinsenhof' à Gand', in: La Flandre Libérale, Gand, 10 avril 1898. 


\section{HET PRINSELIJK HOF TEN WALLE IN GENT}

hedendaagse urbane of suburbane context is dus zeker geen voorrecht van de eigentijdse castellologie.

Een dergelijke structuur bestond uit een omwalde ophoging of motte, met een houten of stenen toren, en een voorhof, eveneens vaak omwald. Het landschap van de Wondelgemmeersen liet geen andere keuze. Men moest diepe, brede grachten graven om hoger gelegen, bewoonbare eilanden te kunnen realiseren. De motteheuvel of het opperhof vertegenwoordigde de adellijke, residentiële en/of militaire betekenis van de site. Het meestal lagere, maar ook opgehoogde en omwalde voorhof bood plaats aan dienstgebouwen, voorraadkamers, ambachtelijke bedrijvigheden en verblijf voor het personeel, soms ook een hal, een huis en een kapel voor de eigenaar-bouwheer en zijn familie. Mottestructuren waren in de 11de en de 12de eeuw een sterk verspreid fenomeen. Doorgaans werden ze opgericht door edelen om hun aanwezigheid in een bepaald gebied te bevestigen tegenover de heer, maar ook tegenover andere edelen en ondergeschikten ${ }^{12}$. Mottekastelen worden vooral geassocieerd met adel wiens macht op territorialiteit was gericht ${ }^{13}$.

Hoewel de oudst bekende geschreven vermelding van de Wal van 1231 dagtekent, is een heel wat oudere origine niet uit te sluiten, en zelfs meer dan waarschijnlijk. De plaats waar het latere Prinsenhof tot ontwikkeling kwam,

12 Zie onder meer: DEBORD, A., 'Châteaux et pouvoirs de commandement', in: Archéologie médiévale, Caen, 1980, nr. 11, p. 72-123; X., 'Les fortifications de terre en Europe occidentale du Xe au XIIe siècles', in: Archéologie médiévale, Caen, 1980, nr. 11, p. 5-71; VERHAEGHE, F., 'Moated sites in Flanders, features and significance', in: HOEKSTRA, T.J., JANSSEN, H.L. \& MOERMAN, I.W.L., Liber Castellorum. 40 variaties op het thema kasteel, Zutphen, 1981, p. 98-121; DE MEULEMEESTER, J., 'Castrale motten in België', in: Miscellanea Archaeologica in honorem H. Roosens, (Archaeologia Belgica, nr. 255), Brussel, 1983, p. 119-225; DE MEULEMEESTER, J., 'Mottes castrales du Comté de Flandre. Etat de la question d'après les fouilles récentes', in: Château Gaillard, Caen, 1983, nr. 11, p. 101-115; DE MEULEMEESTER, J., 'Aardige Aarden Monumenten', in: Monumenten \& landschappen, Brussel, 1985, jg. 4 nr. 3, p. 24-31; DE MEULEMEESTER, J., 'Aarden versterkingen in NoordVlaanderen', in: DE KRAKER, A.M.J., VAN ROYEN, H. \& DE SMET, M.E.E. (red.), Over den vier Ambachten", 750 jaar Keure, 500 jaar Graaf Jansdijk, Kloostersande, 1993, p.137-148; DE MEULEMEESTER, J., 'Le début du château: la motte castrale dans les Pays-Bas méridionaux', in: Château Gaillard, Caen, 1994, nr. 16, p. 121-130; MATTHYS, A. (red.), De la motte au donjon, Namur, 1998; DE MEULEMEESTER, J., 'Archeologie van de Middeleeuwen', in: ART, J. (red.), Hoe schrijf ik de geschiedenis van mijn gemeente? Deel 4. Archeologie, Gent, 1999, p. 392-397.

13 Zie ook DE DECKER, S., 'Vanuit de hoogte. Een vergelijkende studie van de inplanting van castrale mottes in de provincie Oost-Vlaanderen', in: VOBOV-info, Dendermonde, 1999, nr. 49, p. 3-19. De conclusies en beschouwingen van de auteur voor de Gentse sites zijn echter zeer onvolledig en stemmen niet overeen met de bevindingen van het gerealiseerde archeologisch en historisch onderzoek. 


\section{MARIE CHRISTINE LALEMAN}

was grafelijk gebied dat wellicht in 1064 door graaf Boudewijn V (1035$1067)$ in leen werd gegeven aan een burggraaf en bekend stond als 's Burggraven gerechte ${ }^{14}$. Het instellen van de functie van burggraaf of castellanus maakte deel uit van de reorganisatie van het graafschap Vlaanderen in de 11 de eeuw ${ }^{15}$. Dat een burggraaf van Gent in zijn eigen rechtsgebied buiten de toenmalige handelsstad Gent en op enige afstand van het grafelijke kerndomein, het Gravensteen, een mottekasteel oprichtte, paste in de algemene ontwikkeling van wat toen in Noordwest-Europa gangbaar was.

De twee structurele componenten waaruit een mottekasteel was samengesteld, met name een opperhof en een voorhof, zijn terug te vinden op 17de-eeuwse iconografische bronnen die het Prinsenhof in beeld brengen. Op de plattegrond van $1649^{16}$ (afb. 1) wordt het tuineiland in de zuidelijke slotgracht als la motte aangeduid, wat ook aansluit bij gegevens uit de bewaard gebleven, onderzochte rekeningen. Dit tuineiland kan als het opperhof van de middeleeuwse motte worden geïdentificeerd. Op basis van het plan van 1649 kon worden berekend dat het opperhof toen een doormeter had van ca. $45 \mathrm{~m}$ en op zijn minst $3 \mathrm{~m}$ uitstak boven het toenmalige waterpeil van de slotgracht ${ }^{17}$. Oorspronkelijk was de motte ongetwijfeld hoger. De oppervlakte bedroeg zowat 14 are. Bij de projectie van het vermelde plan op de hedendaagse kadastrale situatie blijkt dat het motte-eiland te situeren is in het bouwblok ten zuiden van de Simon de Mirabellostraat, en gedeeltelijk onder die straat (afb. 2). Het plan van 1649 toont aan de noordzijde van het eiland een stenen muur van $14 \mathrm{~m}$ lang met aan de noordoostzijde de resten van wat mogelijk een ronde flankeertoren was. Of dit de overblijfselen waren van een donjon of toren, of van een jonger gebouw, kan thans niet worden uitgemaakt. Het oude voorhof met de eerste dienstgebouwen lag wellicht ten noorden, op de plaats van de latere paleiskern, maar moet als omwald eiland beduidend kleiner geweest zijn dan de situatie op het plan van 1649.

De Wal was als mottekasteel geen geïsoleerd fenomeen. Door archeologisch en gecombineerd historisch onderzoek zijn thans al meerdere mottekastelen

14 VAN DUYSE, P. \& DE BUSSCHER, E., Inventaire analytique des chartes et documents appartenant aux archives de la ville de Gand, Gand, 1867, p. 72-73 nr. 223; HEINS, M., Gand, sa vie et ses institutions, Gand, 1916-1920, deel 2, p. 288-294; FRIS, V., De oude straatnamen van Gent, Gent, 1925, p. 42; GYSSELING, M., Op.cit., p. 31 \& p. 42 en 70.

15 In Gent misschien al kort voor het jaar 1000, ten tijde van graaf Boudewijn IV (988-1035). VERHULST, A., 'Die gräfliche Burgenverfassung in Flandern im Hochmittelalter', in: Vorträge und Forschungen des Konstanzer Arbeitskreises für mittelalterliche Geschichte, Sigmaringen, 1976, S. 266-282.

16 Lille, Archives Départementales de Nord, Série E nr. 2353, P.C. Mercx, Plan de la Cour des Princes à Gand, 1649.

17 Uitwerking door archeoloog Gunter Stoops, Dienst Stadsarcheologie, Gent. 


\section{HET PRINSELIJK HOF TEN WALLE IN GENT}

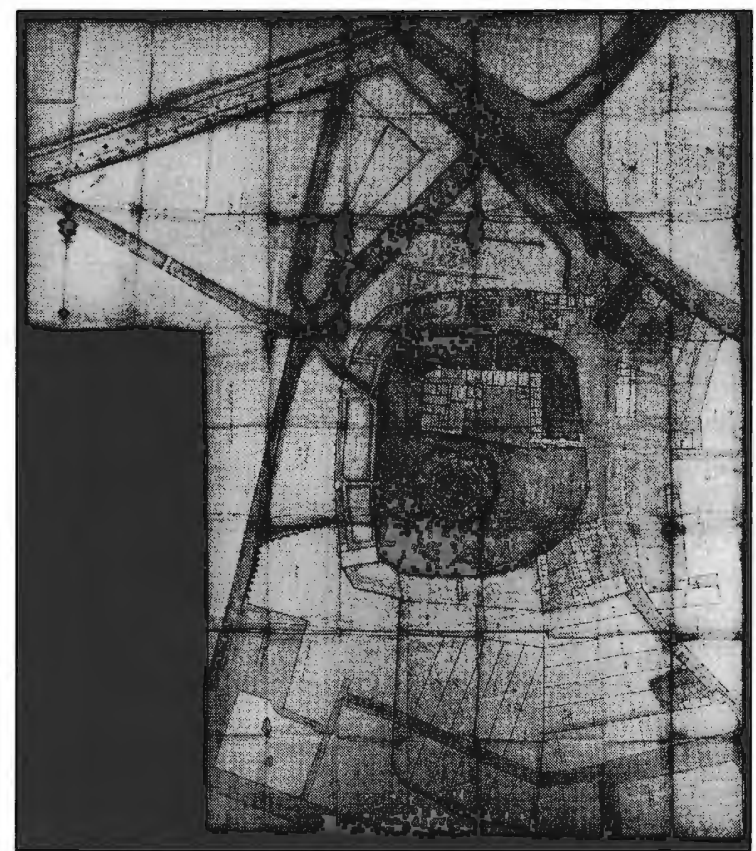

Afb. 1: Het Hof ten Walle naar een plan van P.C. Mercx, 1649 (Foto Archives Départementales du Nord, Lille)

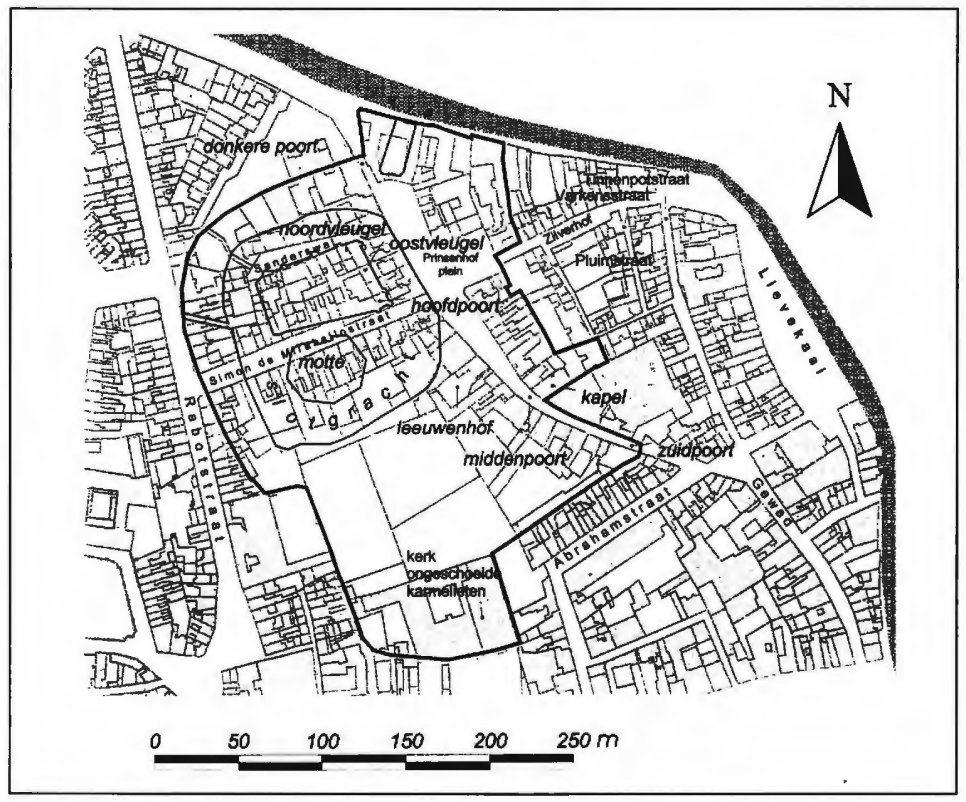

Afb. 2: Situering van de belangrijkste onderdelen van het Hof ten Walle ten opzichte van het hedendaagse kadaster, G. Stoops, 2000 (Plan Dienst Stadsarcheologie, Gent) 


\section{MARIE CHRISTINE LALEMAN}

bekend, die zowat in een krans in het moerasgebied ten westen en ten noorden van de middeleeuwse handelsstad Gent waren opgericht. De bekendste mottestructuur kwam aan het licht bij opgravingen in het Gravensteen ${ }^{18}$. Na een fase met houten gebouwen, die in de 10de eeuw moet worden gesitueerd, werd het centrale gebouw versteend. Dit zaalgebouw van $15 \mathrm{bij} 30 \mathrm{~m}$ en drie bouwlagen hoog stamt waarschijnlijk uit de 11de eeuw. In een volgende fase werd dit centrale gebouw eingemottet. Rondom de bestaande constructie werd een motte opgeworpen, waardoor het gebouw het uitzicht van een donjon kreeg. De aanleg van deze motte kan worden geassocieerd met de regeerperiode van graaf Diederik van de Elzas (1128-1168).

Een ander inmiddels bekend mottekasteel lag ter hoogte van de Steenhuisdreef in Drongen ${ }^{19}$. Archeologisch onderzoek wees de aanwezigheid aan van een mottestructuur met een doormeter van ca. $50 \mathrm{~m}$ en omgeven door een gracht van ca. $10 \mathrm{~m}$ breed, aangelegd in het Leie-alluvium. Uit de thans bekende gegevens blijkt dat dit goed vanaf de late 11de eeuw deel uitmaakte van het bezit van de heren van Aalst ${ }^{20}$. In 1093 zou Boudewijn II van Aalst (1082-1097) Drongen als leen hebben ontvangen van graaf Robert II van Jeruzalem (1093-1111).

Een andere reeds bekende mottestructuur in hetzelfde areaal omheen Gent was het Dobbelslot ${ }^{21}$. Opgravingen duidden op de aanwezigheid van een cirkelstructuur van ca. $45 \mathrm{~m}$ doormeter, met een gracht van $7.5 \mathrm{~m}$ breed. Enkele paalsporen laten vermoeden dat er op de motte een houtbouw stond van 6 bij $7 \mathrm{~m}$. Op het omwalde voorhof bevond zich een kapel. Hoewel de oudste geschiedenis van dit goed vooralsnog slecht bekend is, was het in de tweede helft van de 12de eeuw in het bezit van Zeger II, kleinzoon van burggraaf Zeger I. Ten laatste in 1189 vervulde hijzelf die functie van burggraaf. Uit de geschreven gegevens blijkt dat hij zich als edelman ophield in de dichte omgeving van Filips van de Elzas (1157-1191) en van Boudewijn IX (1194-1205). Deze laatste bevestigde in 1200 de schenking van dat goed in de Briel aan de tempelridders

18 Zie vooral: CALLEBAUT, D., 'Résidences fortifiées et centres administratifs dans la vallée de l'Escaut (IXe- XIe siècle)', in: DEMOLON, P. GALINIE, H. \& VERHAEGHE, F. (eds), Archéologie des villes dans le Nord-Ouest de l'Europe (VIIe - XIIIe siècle), Douai, 1994, p. 93-112.

19 LALEMAN, M.C. \& RAVESCHOT, P., 'Drongen. Een middeleeuwse mote', in: Stadsarcheologie, Gent, 1981, jg. 5 nr. 2, p. 2-27.

20 Zie onder meer: WARLOP, E., De Vlaamse adel vóór 1300, Handzame, 1968, dl. 1, passim \& dl. 2, p. 3-10. Zie ook: DE MYTTENAERE, A, e.a., Galbert van Brugge. De moord op Karel de Goede, Antwerpen, 1978, passim.

21 DESMET, G. \& RAVESCHOT, P., 'Dobbelslot 1. Onderzoek van een bedreigd terrein', in: Stadsarcheologie, Gent, 1980, jg. 4 nr. 1, p. 20-26; ERVYNCK, A., e.a., Dobbelslot-Ridderslot. Tentoonstelling, Gent, 1991; LALEMAN, M.C. \& RAVESCHOT, P., 'Enkele kritische bedenkingen over Gentse ruiterstatuettes', in: Stadsarcheologie. Bodem en monument in Gent, Gent, 1991, jg. $15 \mathrm{nr} .1$, p. 34-42. 


\section{HET PRINSELIJK HOF TEN WALLE IN GENT}

voor de inrichting van een tempelhuis in Gent. Het Tempelhof was daar gevestigd van 1200 tot in 1312, toen het samen met de andere ordebezittingen werd overgedragen aan de orde van Sint-Jan of de Johannieters.

Wetenschappelijk gezien hoort de Wal thuis in de inventaris van de mottekastelen die over Vlaanderen verspreid liggen. Het is evenwel duidelijk dat het niet gaat om een duidelijk herkenbaar momument dat nog 'gaaf' bewaard is, indien dit laatste al zou kunnen. De nog in het landschap of bij dorpskernen herkenbare monumenten hebben evenwel niet dezelfde ontwikkeling ondergaan. De Wal in Gent behoort tot de mottekastelen die zich tot een adellijke/vorstelijke residentie hebben kunnen ontplooien en werd door de ontwikkeling van de stad vanaf de late 18 de eeuw bovengronds onherkenbaar. Is de site daarom minder betekenisvol? Vanuit wetenschappelijk standpunt zeker niet. Het lijkt ons dan ook bijzonder gevaarlijk om de zichtbare monumentwaarde en de veronderstelde gaafheid van een motteheuvel als evaluatiecriteria naar voren te schuiven voor een bescherming als waardevolle erfgoedsite. Indien dit wel het geval zou zijn, dan mist Vlaanderen in elk geval belangrijke hoofdstukken van haar beschavingsgeschiedenis, zeker in de steden en de randstedelijke gebieden. Moet de waarde van een dergelijke middeleeuwse site door uitgebreide opgravingen worden bewezen? Rekening gehouden met de toch vrij intensieve tendens tot vernieuwing van de bebouwing in het Gentse Prinsenhofwijk is het vooral noodzakelijk om beheersmaatregelen te voorzien voor het gehele areaal van de Wal, die archeologisch en bouwarcheologisch onderzoek verplicht maken voorafgaand aan elk renovatieproject. Dat dit, op een enkele uitzondering na, nooit grootschalig kan zijn, blijkt uit de dichte perceelsstructuur en de versnipperde eigendomssituatie, die beide een realiteit zijn. Dat de oorspronkelijke topografie, met de waterzieke moerasgronden van de Wondelgemmeersen, het archeologisch bodemonderzoek in dat deelgebied niet vergemakkelijkt, is evident. Toch lijken de vermelde beheersmaatregelen ons noodzakelijk om voorafgaand aan verdere degradatie met erfgoedvernieling een nog beter inzicht te krijgen in dit randstedelijke gebied dat thans een onderdeel is van Gent. Het is echter evenzeer noodzakelijk dat het verdere onderzoek geschiedt vanuit een globale visie over dit deelgebied en met de betrokkenheid van de archeologen, historici en bouwhistorici die deze site goed kennen.

Vóór 25 juni 1231 verkochten burggraaf Hugo II en zijn echtgenote Oda de Champlitte de Wal aan Alexander Braem 22 . De koper ${ }^{23}$ was zoon van

22 VAN DER HAEGHEN, V., Op. cit. p. I en p. 4-6; BLOCKMANS, F., Het Gentsche..., p. 402-403.

23 BLOCKMANS, F., 'Peilingen nopens de bezittende klasse te Gent omstreeks 1300', in: Revue belge de philologie et d'histoire, Bruxelles, 1937, nr. 3-4, p. 632-665; BLOCKMANS, F., Het Gentsche..., p. 290-291, p. 297, p. 314-315, p. 344-347 en passim. 


\section{MARIE CHRISTINE LALEMAN}

Boudewijn Braem en kleinzoon van Abraham de Gandavo, dus uit Gent. Hij was een telg uit een bekende Gentse familie van erfachtige lieden, kooplui en schepenen. Zelf was Alexander Braem actief als lakenkoopman en verwierf hij een opmerkelijk fortuin. Met de winst van zijn handelsactiviteiten kon hij beleggen in onroerend goed, zowel in Gent als in de omgeving van Hulst. Het rijke handelspatriciaat, waartoe Braem behoorde, trachtte zich steeds meer met de adel te verweven. Geldgebrek noopte de edelen vaak tot verkoop van bezittingen aan kapitaalkrachtige, erfachtige lieden ${ }^{24}$, wat ook met de Wal in 1231 geschiedde. Alexander Braem liet zich daarenboven ridder noemen en wijzigde de naam in Sersanders. Zijn dochter Avezoete kon hij door huwelijk binden met Vilain, broer van de toenmalige Gentse burggraaf. Wat Alexander Braem-Sersanders en zijn erfgenamen met het Hof ten Walle aanvingen, is niet bekend. Er werden vooralsnog geen materiële resten of aanwijzingen gevonden die met deze eigenaarsfamilie kunnen worden geassocieerd. Alleen de straatnaam Sanderswal voor de Cul de sac de la Cour, die in de 19de eeuw op de gedempte noordelijke slotgracht werd aangelegd, herinnert nog aan deze eigenaars.

Toch veranderde de structuur en het uitzicht van de Wal in de 13de eeuw. In een zoektocht naar betere verbindingswegen voor de Gentse handel vatte het stadsbestuur midden 13de eeuw het initiatief om een kanaal te graven tussen Gent en de Zwinhaven aan de Noordzee ${ }^{25}$. Gravin Margaretha van Constantinopel (1244-1278) verleende daarvoor de nodige toestemmingen in 1251. Aanvankelijk leek de meest logische verbinding Gent-Aardenburg, maar zeker in 1262 was er al sprake van een vertakking naar Damme, wat uiteindelijk de voornaamste waterweg werd. Economisch gezien bood Damme een aantal voordelen zoals de nabijheid van Brugge, terwijl Damme een jaarmarkt had, evenals een stapelrecht op wijn en haring. Hoe de bouwactiviteiten voor het kanaal vanuit Gent werden georganiseerd, is nog onvoldoende bestudeerd. Alleen het tracé bleef herkenbaar. Waar mogelijk, werden bestaande waterlopen aangepast, zoals de Leie-arm naast het Gravensteen. Meer westelijk, onder meer voor het tracé dat thans tussen Molenaarstraat en Rabot te situeren is, werd een nieuwe verbinding gegraven. Daarvoor was grafelijke toesteming nodig. Het kanaal doorkruiste er immers het 's Burggraven gerechte. De gronden die tussen 1251 en 1269 werden verworven voor de aanleg van de Lieve, werden eigendom van de stad Gent die tevens de leiding had van de hele onderneming. De verplichtingen voor het onderhoud van de waterweg, het functioneren van de sluis in Damme, de regelmatige inspectie

24 BLOCKMANS, F., Het Gentsche..., passim.

25 Zie vooral: BOES, J., De Lieve, eerste kunstmatige verbinding tussen Gent en de zee, Gent, 1929; NOWE, H., 'Het streven van Gent naar de zee, XIIIe-XIXe eeuw', in: Handelingen der Maatschappij voor Geschiedenis en Oudheidkunde, Gent, 1952, p. 21-41. 
en maatregelen om overstroming van omliggende gronden te voorkomen, gaf de stad in pacht, wat een winstgevende functie was in de periode van de 13de tot de 16de eeuw. Door het graven van de Lieve verloor de Wal terrein en kwam het meest noordelijke deel van het goed 'aan de overzijde van de Lieve' te liggen.

\section{De eerste verkavelingen}

Via diverse akten ging de Wal in 1323 van de erfgenamen Sersanders over op Simon de Mirabello (ca. 1280-1346) ${ }^{26}$, die ook heer van Halen werd genoemd naar een landgoed bij Diest waarvan hij tevens eigenaar was. Als natuurlijke zoon van een steenrijke geldwisselaar van Italiaanse origine, Giovanni of Jan de Mirabello, zette hij de bankiersfunctie van zijn vader voort ${ }^{27}$. Hij leende geregeld belangrijke bedragen aan particulieren, religieuze instellingen, steden - onder meer Gent en Brugge -, maar ook aan de graaf van Vlaanderen, de hertog van Brabant, de koning van Hongarije en de Engelse koning Edward III. Hij was gehuwd met Elisabeth (Isabella) van Lierde, vrouw van Zomergem, bastaarddochter van Lodewijk I van Nevers (+1322). Aanvankelijk sloot hij zich aan bij de Fransgezinde strekking van graaf Lodewijk II van Nevers (1322-1348) 28 , voor wie hij vaak optrad tussen 1332 en 1338. Dit veranderde echter toen Jacob van Artevelde Gent kon overhalen om een anglofiele koers te kiezen. Door een handelsakkoord kon de Engelse wol, basisproduct van de lakennijverheid, Vlaanderen opnieuw binnen. Eind 1340 was de economische crisis overwonnen en was ook de rol van Gent uitgespeeld, maar de radicale strekking binnen het weversambacht wilde de strikte alliantie met Engeland verderzetten. In de conflicten die ermee gepaard gingen, werd Jacob van Artevelde op 17 juli 1345 van het leven beroofd. Nog geen jaar later, op 9 mei 1346, werd Simon de Mirabello eveneens vermoord aangetroffen. Zijn stoffelijke resten werden bijgezet in de Sint-Veerlekerk.

Wat deed Simon de Mirabello met de Wal die hij in 1323 had verworven? Tot nu nog toe zijn weinig concrete gegevens bekend, hoewel op grond van een aantal indicaties nieuwe inzichten kunnen worden geformuleerd. De Wal was slechts een van zijn vele onroerende bezittingen. Bij zijn verblijf in Gent resideerde hij in een stenen huis, het Ser Symoenssteen, nabij de Burgstraat. Dit is dus te situeren aan de rand van de huidige Prinsenhofwijk, een terrein

26 VAN DER HAEGHEN, V., Op. cit., p. II-III.

27 ROGGHE, P., 'Simon de Mirabello in Vlaanderen', in: Appeltjes van het Meetjesland, Eeklo, 1958, nr. 9, p. 5-56.

28 VANDERMAESEN, M., 'Lodewijk II van Nevers', in: Nationaal Biografisch Woordenboek, Brussel, 1971, deel 5, p. 531-533. Zie ook: PREVENIER, W. \& BOONE, M., 'De 'stadstaat'-droom', in: Gent, apologie van een rebelse stad, Antwerpen, 1989, p. 80-105. 


\section{MARIE CHRISTINE LALEMAN}

dat in het begin van de 14de eeuw nog tot de Wal behoorde. De Abrahamstraat heette aanvankelijk trouwens de Ser Symoenstrate ${ }^{29}$, naar Simon van Halen, alias de Mirabello. Het huis dat Simon de Mirabello bewoonde moet misschien worden gelokaliseerd in het bouwblok tussen Burgstraat en Abrahamstraat. Of dit huis dan kan worden vereenzelvigd met het Dondersteen dat in het begin van de 17de eeuw tot Berg van Barmhartigheid werd omgevormd, moet nog verder worden onderzocht. Werd het Ser Symoenssteen door De Mirabello opgetrokken of trok hij in een reeds bestaand gebouw in? Het ging in elk geval om een stenen huis met adellijke context, dat buiten de 12 de-eeuwse stadsomwalling was gelegen, en daarom hoort het ook niet thuis bij de particuliere stenen stadshuizen, de zogenoemde Stenen die de handelsstad Gent in de 12 de en de 13 de eeuw kenmerkten ${ }^{30}$. Of liet De Mirabello de woning optrekken in een geheel nieuwe stedelijke context, waarbij de Burgstraat als verbindingsweg aan belang won. Het gedeelte van het 's Burggraven gerechte, begrepen tussen Lieve, Schipgracht, en Hoogstraat, werd immers in 1300 door de stad aangekocht ${ }^{31}$. Naderhand werd er omheen die westelijke stadsuitbreiding een nieuwe verdedigingsgordel aangelegd.

Indien Simon de Mirabello een stenen residentie had tussen de Burgstraat en de Abrahamstraat, dan huisde hij wellicht niet op de motte van de Wal, mogelijk omdat de verouderde structuur niet meer beantwoordde aan het imago dat hij met zijn hof wenste uit te dragen. De oude Wal met zijn afhankelijkheden makkte evenwel nog steeds deel uit van hetzelfde goed dat in die tijd nog heel wat uitgestrekter was dan de thans bekende configuratie van het Prinsenhof.

Het recente projectonderzoek reikte immers een hele reeks aanwijzingen voor de verkaveling van gronden die oorspronkelijk tot de Wal behoorden. Een belangrijke factor bij die verkaveling was de oprichting van een klooster waaraan middelen werden toegekend om te kunnen voortbestaan. In 1340 immers vatte Simon de Mirabello het plan op om in de Wal een klooster van victorinen op te richten, religieuzen die de regel van Augustinus volgden en bij de congregatie van Saint-Victor waren aangesloten. Voor de stichting werden schenkingen onder de vorm van renten voorzien. De plaats wordt toen beschreven als leur mayson a Ghand, que on appiele le Wal en flamenc, avec toutes les appertenanches qui appertienent a le dicte mayson, chest assavoir

29 FRIS, V., De oude straatnamen van Gent, Gent, 1925, p. 20.

30 LALEMAN, M.C. \& RAVESCHOT, P., Inleiding tot de studie van de woonhuizen in Gent. Periode 1100-1300. De kelders, (Verhandelingen Koninklijke Academie voor Wetenschappen. Letteren en Schone Kunsten van België), Brussel, 1991; LALEMAN, M.C., 'De Gentse Stenen: getuigen van handel in laken, graan en bouwstenen', in: Rotterdam Papers, Rotterdam, 1992, nr. 7, p. 61-73.

31

GYSSELING, M., Op.cit., p. 31 \& p. 42 nr. 70. 
toute le circuite ensi comme elle est muree ${ }^{32}$. Op 10 maart 1341 (n. st.) verleende graaf Lodewijk van Nevers zijn goedkeuring aan die stichting. Via een bul van 4 juli 1343 van paus Clemens VI (1342-1352) kregen de religieuzen de Sanderswal, waar zij een vrouwenklooster mochten oprichten met kerk, kerkhof, refter en alle andere noodzakelijke plaatsen. In zijn testament van 15 januari 1346 bevestigde Simon de Mirabello deze stichting en schatte hij het daaraan voorbehouden inkomen op een bedrag van 800 pond parisis. De dood van Simon de Mirabello verijdelde evenwel de verdere realisatie.

In hoeverre er buiten de officiële beslissingen al iets was gebeurd, is niet zo duidelijk. De uitvoerders van het testament zorgden wel voor de aankoop van goederen en voor renten ten behoeve van het klooster sente Barbele ten Walle. Uit een geschreven vermelding van $1349^{33}$ kunnen we afleiden dat er in 1349 , in een uithoek van het Hof ten Walle, een kapel was gebouwd en het terrein errond als klein kerkhof was bestemd. De kapel zou in dat jaar gewijd zijn door bisschop David de Janua in opdracht van bisschop Johannes Pratanus uit Tournai (Doornik). Waar we die kapel moeten situeren binnen het gehele 14de-eeuwse areaal van Ten Walle, is niet bekend. Er zijn in elk geval geen materiële sporen teruggevonden. En aangezien er duidelijk sprake is van een uithoek, kan er ook geen relatie zijn met de latere residentiële hofkapel.

De hoofdreden waarom het klooster niet in de Wal werd gerealiseerd, lag bij graaf Lodewijk van Male (1346-1384), die andere plannen had met het goed $^{34}$. De verwerving van de Wal door de graaf was zo goed als een confiscatie voor de antigrafelijke en Engelsgezinde koers die Simon de Mirabello in zijn laatste levensjaren had gevolgd. De graaf achtte de Wal ongeschikt voor de vestiging van een klooster, maar vond het een ideaal uitgangspunt voor de oprichting van een castrum, een versterkt kasteel als opvolger voor het verouderde Gravensteen. Er moesten echter eerst oplossingen worden gevonden voor de erfgenamen van Simon de Mirabello en voor de door paus Clemens VI goedgekeurde kloosterstichting. Een akte van 8 mei 1353 bevestigde Lodewijk van Male als eigenaar van de Sanderswal met de bijbehorende weiden, boomgaarden en afhankelijkheden. Elisabeth van Lierde, inmiddels hertrouwd met Arnold van Heule, heer van Rummen, mocht tot aan haar dood een deel van de residentie bewonen. Ging het om het Steen bij de Burgstraat, om het oudere opperhof of om een ander, thans nog niet bekend gebouw? Nieuw onderzoek zal dit moeten uitwijzen. Met paus Innocentius VI (1352-

32 VAN DER HAEGHEN, V., Op. cit., p. V-VII en p. 34-39. Zie ook: MARECHAL, G., Inventaris van het archief van de Abdij van Groenenbriel te Gent, Brussel, 1975. Zie ook SAG, Reeks XLVI, Groenenbriel; DECAVELE, J. \& VANNIEUWENHUYSE, J., Archiefgids. I. Oud Archief, Gent, 1983, p. 229

33 VAN DER HAEGHEN, V., Op. cit., p. VII-VIII.

34 VAN DER HAEGHEN, V., Op. cit., p. VIII-XII. 


\section{MARIE CHRISTINE LALEMAN}

1362) kwam er op 6 april 1362 een akkoord tot stand voor de mislopen kloosterstichting. De religieuzen kregen de beschikking van een huis met walgracht en met bijbehorende meersen en goederen, die burggraaf Philip Vilain in de Briel bezat en eveneens in het 's Burggraven gerechte gelegen was ${ }^{35}$. Beatrice Vlaminc uit het klooster Blijdenberg bij Mechelen werd op 18 oktober 1370 als eerste priorin aangesteld ${ }^{36}$. Op 1 december 1372 werd het klooster verheven tot de abdij Sint-Margareta ter Groenen Briele ${ }^{37}$.

De gronden die van de Wal werden afgenomen, werden nog in de 14de eeuw verkaveld en bebouwd. Dit geschiedde wellicht in de eerste helft van de 14de eeuw, of beter omstreeks 1340-1341, omdat er op de nieuwe huizen renten werden bezet voor de abdij van de Groene Briel. Dit werd voor het eerst duidelijk bij het projectonderzoek van het Elisabethhuis, gelegen in de smalle strook tussen Sint-Elisabethbegijnhof en de Wal, aan de huidige Rabotstraat ${ }^{38}$. Mogelijk werd ook het reeds vermelde bouwblok tussen de Burgstraat en de Abrahamstraat toen geprivatiseerd. De gronden aan de noordzijde van de Abrahamstraat hebben een ontwikkelingsgeschiedenis die vanaf het tweede kwart van de 14de eeuw kan worden gevolgd. Aan de oostzijde lijkt ook het deelgebied met het Zilverhof, de Pluimstraat, de Varkensstraat en de Tinnenpotstraat toen afgesplitst. De oudste bewoningssporen dagtekenen van de 14de eeuw. Het ging om een systematische verkaveling die vanuit de Wal werd georganiseerd en geïnspireerd was door de nabijgelegen stad, wat onder meer blijkt uit de oorspronkelijke straatnamen zoals Hoogpoort en Onderstraat. Het deelgebied behield zijn buitenstedelijke, ietwat speciale statuut en was tot 1776 niet aan stedelijke reglementeringen onderworpen ${ }^{39}$.

De littekens van deze verkaveling, een heel specifieke vorm van randstedelijke ontwikkeling in de late Middeleeuwen, zijn over het hele deelgebied in de aanleg van het openbaar domein en de perceelsstructuur terug te vinden. Ondanks de overwegend jongere bebouwing, zijn heel wat percelen in oorsprong 14de-eeuws. Hoe kan men met een dergelijk erfgoed omgaan? De betekenis is niet vanop straat af te lezen of in het monumentale patrimonium zichtbaar. Grootschalige opgravingen om de historische betekenis ervan te 'bewijzen', zijn bij een dergelijke kleinschalige perceelsindeling in bebouwd stedelijk milieu niet mogelijk. Het kleinschalig archeologisch onderzoek, bodem- en muuronderzoek, ondersteund door gegevens uit andere bronnen, hebben evenwel de historisch-wetenschappelijke waarde van dit verkave-

35 VAN DER HAEGHEN, V., Op. cit., p. XIII-XIV.

36 VAN DER HAEGHEN, V., Op. cit., p. XIV.

37 VAN DER HAEGHEN, V., Op. cit., p. XIV.

38 BARBRY, N., e.a., Huizenonderzoek in Gent. Het Elisabethhuis, Gent, 1997, vooral p. 21-23.

39 Rijksarchief Gent, Fonds Vorstelijke Domeinen, nr. 74. Met dank aan Daniel Lievois voor het bezorgen van deze inlichtingen. 
lingsproces binnen de Gentse context voldoende bewezen. Alleen beschikt Vlaanderen niet over de geschikte ingesteldheid en de noodzakelijke voorzieningen om dit aspect van het erfgoed voor de toekomst te behouden en kan de degradatie zich gestaag voortzetten.

\section{Bouwheren en 'bouwvrouwen'}

In 1366 werd de Wal eigendom van graaf Lodewijk van Male die het goed voortbestemde als grafelijke residentie ${ }^{40}$. Om redenen van uitstraling en comfort werd het Gravensteen als verblijfplaats eerst verlaten voor het Hof van Posteerne, nabij de Houtlei, en korte tijd nadien voor de Wal. Mede omwille van die functieverschuiving is het logisch te veronderstellen dat Lodewijk van Male het eigendom grondig liet verbouwen. Het werd evenwel geen castrum, geen versterkt kasteel, want behalve het Gravensteen zelf kreeg later alleen het Castrum Novum (het Spanjaardenkasteel) die naam en de verdedigingsfunctie. Een tweede gegeven dat ongetwijfeld een rol speelde bij de verbouwing van de Wal was het huwelijk van dochter Margaretha van Male (13841405) met de Bourgondische hertog Filips de Stoute (1384-1404). De huwelijksplechtigheid vond plaats in Gent op 19 juni 1369. Drie dagen lang werd er in het Hof ten Walle feest gevierd. De teruggevonden geschreven gegevens bieden evenwel geen duidelijk beeld over een bouwcampagne of verbouwing, maar handelen vooral over de verfraaiing van de residentie, vanaf 1361-1362, met beeldhouwwerk, schilderwerk en meubilair ${ }^{41}$. Voor het beeldhouwwerk deed men een beroep op Sanders de Tournay, waaruit we kunnen afleiden dat er monumentale sculptuur van Doornikse steen was. Voorts was er schilder Jan van der Asselt die voor de kapel een reeks grafelijke portretten maakte ${ }^{42}$. Mogelijk waren die te vergelijken met de schilderingen die in 1374 in de gravenkapel van de Onze-Lieve-Vrouwekerk in Kortrijk ${ }^{43}$ werden uitgevoerd.

40 Ter vergelijking: in Brugge wordt er voor het eerst in 1396 melding gemaakt van een grafelijke residentie tussen de Noordzandstraat en de Moerstraat, de plaats van het latere Prinsenhof. Een beperkt archeologisch onderzoek bracht sporen aan het licht uit de eerste helft van de 13de eeuw. Ze wezen op het bestaan van een houtbouw voorafgaand aan de grafelijke vestiging. Zie: DE WITTE, H. \& HILLEWAERT, B., Archeologisch jaarrapport 1997-1999, Brugge, 2000, p. 153-154.

41 VAN ELSLANDE, R., 'Kunstenaars werkzaam in de grafelijke residenties te Gent tijdens de 14e eeuw', in: Ghendtsche Tydinghen, Gent, 1995, jg. 24 nr. 1, p. 325-334.

42 VAN ELSLANDE, R., 'Jan van der Asselt, hofschilder van Lodewijk van Male', in: De Leiegouw, Kortrijk, 1987, jg. 29 nr. 7, p. 420-444; VAN ELSLANDE, R., 'Kunstenaars...', p. 327.

43 DEVLIEGHER, L., De Onze-Lieve-Vrouwekerk te Kortrijk, (Kunstpatrimonium van West-Vlaanderen, nr. 6), Tielt-Utrecht, 1973, p. 14-15. Zie ook: BERGMANS, A, Middeleeuwse muurschilderingen in de 19de eeuw, (Kadoc Artes, nr. 2), Leuven, 1998, p. 82-88. 


\section{MARIE CHRISTINE LALEMAN}

Van der Asselt voerde nog wel meer opdrachten uit voor Lodewijk van Male en diens opvolger in het graafschap Vlaanderen, de Bourgondische hertog Filips de Stoute. Ook in 1369 bevestigde Philippe d'Arbois, bisschop van Tournai (Doornik), de stichting van twee kapelaniën in de capella inferiori sita et constructa, wat kan worden vertaald als de benedenkapel die Lodewijk van Male in de Wal had laten bouwen.

Uit de bestudeerde geschreven inlichtingen blijkt dat André Beauneveu en Melchior Broederlam, twee topkunstenaars uit de late 14de eeuw, in het Hof ten Walle werkzaam waren. In 1381 vervaardigde Beauneveu, die vooral een beeldhouwer was, noz ymaiges voor Lodewijk van Male ${ }^{44}$. Broederlam realiseerde in 1385 en in 1396 voor hertog Filips de Stoute in de Gentse residentie onder meer decoratieve versieringen uit en schilderde grote blazoenen met voorstelling van het wapenschild van Bourgondië ${ }^{45}$. In 1396 werd ook glasmaker Jacques le voirier vergoed voor de uitvoering van verscheidene opdrachten in de kapel en de kamers van de residentie ${ }^{46}$. Het beeld dat de eerder beperkte geschreven inlichtingen bieden, laat vermoeden dat het Hof ten Walle toen reeds een goed georganiseerd adellijk paleis was. De tewerkstelling van Beauneveu en Broederlam, die men ook terugvindt aan het Bourgondische hof van Dijon, is kenmerkend voor de figuur van Filips de Stoute, broer van de Franse koning Charles V (1364-1380) en van de grote kunstmecenas Jean de Berry (+ 1416). Hij bracht de Franse levensstijl, met internationale culturele inbreng en elementen van de spektakel-staat-idee naar Vlaanderen. Met stijl, geld en vertoon trachtte hij politieke tegenstanders voor zich te winnen, wat in Vlaanderen met zijn machtige steden niet zo makkelijk was ${ }^{47}$. Geregeld waren er dan ook conflicten tussen de centralisatiepolitiek van de Bourgondische hertogen en het streven naar stedelijke autonomie.

De geschreven bronnen geven voorts aan dat vooral Filips de Goede (14191467) de grote bouwheer was van de Gentse residentie, mede omwille van goed gedocumenteerde bouwrekeningen onder meer voor de periode van

44 VAN ELSLANDE, R., 'Kunstenaars...', p. 329.

45 VAN ELSLANDE, R., 'Kunstenaars...', p. 329-331.

46 VAN ELSLANDE, R., 'Kunstenaars...', p. 331 en p. 334.

47 BOONE, M., 'Het hof van de hertogen van Bourgondië: macht, imago en status', in: LALEMAN, M.C. (dir.), Op.cit., p. 72-76. Zie ook: PREVENIER, W. \& BLOCKMANS, W., De Bourgondische Nederlanden, Antwerpen, 1983; BOONE, M., Gent en de Bourgondische hertogen, Brussel, 1990; BLOCKMANS, W. \& PREVENIER, W., De Bourgondiers. De Nederlanden op weg naar eenheid, 1384-1530, Amsterdam-Leuven, 1997. 


\section{HET PRINSELIJK HOF TEN WALLE IN GENT}

1421 tot 142948 . Omwille van de grootte van de geplande bouwactiviteiten stelde Gautier Poulain, algemeen ontvanger van Vlaanderen, op 23 november 1422 Gentenaar Jacob de Smitere aan om deze onderneming te leiden. Het Hof ten Walle was evenwel geen onbebouwd terrein. Wel was het hof kort daarvoor door brand verwoest ${ }^{49}$. Tussen 1441 en 1446 volgde er een tweede bouwcampagne onder leiding van Jacob de Smitere. Welke oudere gebouwen bleven overeind en werden in de 15de-eeuwse organisatie opgenomen? In tegenstelling tot wat in de oudere literatuur algemeen gangbaar is, was Filips de Goede niet de enige bouwheer van een kasteel dat ook niet als totaal concept in één keer werd gerealiseerd. Andere leden van de hertogelijke familie die in de Gentse residentie verbleven, drukten eveneens hun stempel op de structuur, de organisatie, de bouwkundige ontwikkeling en uiteraard ook op het hofleven tijdens hun verblijf. Tot de andere hoofdfiguren van het Gentse Hof ten Walle behoren Michèle de France (1395-1422), Isabella van Portugal (1397-1471), Karel de Stoute (1467-1477), Margaretha van York (1446-1503) en Maria van Bourgondië (1477-1482) die op 19 augustus 1477 in de Gentse residentie huwde met Maximiliaan I van Oostenrijk (1482-1494). Voorts waren er Filips de Schone (1493-1506) en zijn echtgenote Johanna van Castillië (1504-1555) die er vanaf oktober 1499 verbleef om de geboorte van een volgende telg en mogelijke troonopvolger voor te bereiden. In het schrikkeljaar 1500, op 24 februari, zag Karel van Luxemburg (de latere Karel V) in de Gentse residentie het levenslicht ${ }^{50}$. Behalve hijzelf drukten ook nog landvoogdes Margareta van Oostenrijk (1507-1530), Eleonora van Oostenrijk en Maria van Hongarije (1531-1555) hun stempel op de uitbouw van het Gentse hof $^{51}$.

48 Zie ook BOONE, M., 'Het Prinsenhof', in: BAILLEUIL, B., e.a., Een stad in opbouw. Gent voor 1540, Tielt, 1989, p. 296-300. Zie ook BOONE, M. \& de HEMPTINNE, T., 'Espace urbain et ambitions princières: les présences matérielles de l'autorité princière dans le Gand médiéval (12e siècle-1540)'; in: PARAVICINI, W. (ed.), Zeremoniell und Raum (Residenzforschung, nr. 6), Sigmaringen, 1997, p. 297303. Zie verder ook: VAN ELSLANDE, R., 'Jan Eebins ( \pm 1345-1412), metselaar, beeldhouwer, architect en landmeter', in: Ghendtsche Tydinghen, Gent, 1991, jg. 20 nr. 3, p. 142-160.

49 Uit de rekeningen blijkt dat niet enkel het residentiële gedeelte maar ook de kapel, de stallingen, de bruggen en het leeuwenhof getroffen werden. Van deze brand werden archeologisch geen sporen teruggevonden.

50 VERMEIR, R., 'Grote kanonnen en kleine Karels: city-marketing, gemeenteraadsverkiezingen en geschiedenis', in: Handelingen der Maatschappij voor Geschiedenis en Oudheidkunde te Gent, Gent, 2000, nr. 54, p.3-16.

51 Zie vooral LIEVOIS, D., 'Het Hof ten Walle...', p. 158-191. 


\section{MARIE CHRISTINE LALEMAN}

De vroeger opgestelde en recent aangevulde itineraria ${ }^{52}$ laten toe vast te stellen wanneer elk van hen met hun hofhouding in Gent verbleef. De aankomst werd voorafgegaan door een koortsachtige drukte van allerlei bouw- en herinrichtingwerkzaamheden waarvan duizenden items in de rekeningen getuigenis afleggen. Het hof was reizend en verbleef wisselend in de vele residenties verspreid over Bourgondië, Paris en de Nederlanden. Tijdens de afwezigheid van de hertogelijke familie werd het hof nauwelijks onderhouden. Alleen het 'karkas' bleef trouwens achter, want alle meubilair en heel wat onderdelen van de inrichting reisden mee, wat door de koerierdienst van de hertogelijke hofhouding werd georganiseerd. Telkens wanneer de hertog, de hertogin of een ander belangrijk familielid zich aanmeldden, werden de gebouwen opgeknapt, hersteld, opnieuw ingericht en hermeubeld, of afgestemd op de speciale eisen van hun hoofdbewoners. Veel van deze activiteiten zijn niet archeologisch of bouwkundig terug te vinden. Ze laten evenwel toe het materiële kader dat via andere bronnen kan worden opgespoord, in te vullen met het leven waartoe het 'stenen' huis met al zijn onderdelen de omkadering vormde.

Het beeldmateriaal dat concrete inlichtingen verschaft over het Hof ten Walle is voornamelijk $17 \mathrm{de}$-eeuws en geeft derhalve een synthese weer van alles wat tot die tijd was gerealiseerd en dan nog zichtbaar was ${ }^{53}$. Bij het ontwarren van de bouwchronologie is het belangrijk daarmee rekening te houden. De datering van de materiële resten is evenmin evident. Diverse gebouwonderdelen worden steeds 15 de-eeuws gedateerd omdat alleen enkele 15 de-eeuwse campagnes bekend waren. Omwille van de fragmentarische bewaringstoestand, het unieke van de typologie of het ontbreken van bruikbare dateringsgegevens blijft een meer gedifferentieerde chronologie van de archeologische relicten niet evident. Toch biedt het recente onderzoeksproject een aantal nieuwe

52 VANDER LINDEN, H., Itinéraires de Marie de Bourgogne et de Maximilien d'Autriche, 1477-1482, Bruxelles, 1934; VAN DER LINDEN, H., Itinéraires de Charles, duc de Bourgogne, Marguerite d'York et Marie de Bourgogne, 1467-1477, Bruxelles, 1936; VAN DER LINDEN, H., Itinéraires de Philippe le Bon, duc de Bourgogne (1419-1467) et de Charles, Comte de Charolais (1433-1467), Bruxelles, 1940. Aan te vullen met LIEVOIS, D., 'Op bezoek bij de hertogen van Bourgondië', in: LALEMAN, M.C. (dir.), 2000, p. 77-84; LIEVOIS, D., Het Hof, p. 135-191. Zie ook: BOONE, M., 'Het Hof', p. 72-76.

53 Behalve het reeds vermelde plan van 1649 en een gravure in de Flandria Illustrata van Antonius Sanderus (1641) (afb. 3) bewaart het Bijlokemuseum een anoniem 17de-eeuws schilderij met voorstelling van de doopstoet van Keizer Karel (Gent, Bijlokemuseum, Inv. 164) (afb. 4). Als iconografische bron geeft het schilderij de kern van het Prinsenhof weer, vanaf de oostzijde, zoals de residentie zich in de 17de eeuw voordeed. Zie: ook: DE SCHRIJVER, A. \& VAN DE VELDE, C., Catalogus van de schilderijen Stad Gent, Oudheidkundig Museum. Abdij van de Bijloke, Gent, 1972, p. 204-205. 


\section{HET PRINSELIJK HOF TEN WALLE IN GENT}

inzichten die goed aansluiten bij wat over vergelijkbare residenties in de Nederlanden en elders bekend is ${ }^{54}$.

\section{Het Hôtel de la Motte}

De onregelmatige vorm van het areaal zoals het zich thans ook nog in het stedelijke perceelsweefsel aftekent (afb. 1), omsluit een areaal van 8 hectare en was wellicht al een feit in het midden van de 14de eeuw als gevolg van de verkavelingen van de 'randen' van de Wal ten tijde van Simon de Mirabello. Behalve aan de oostzijde bleef de bakstenen omheiningsmuur grotendeels

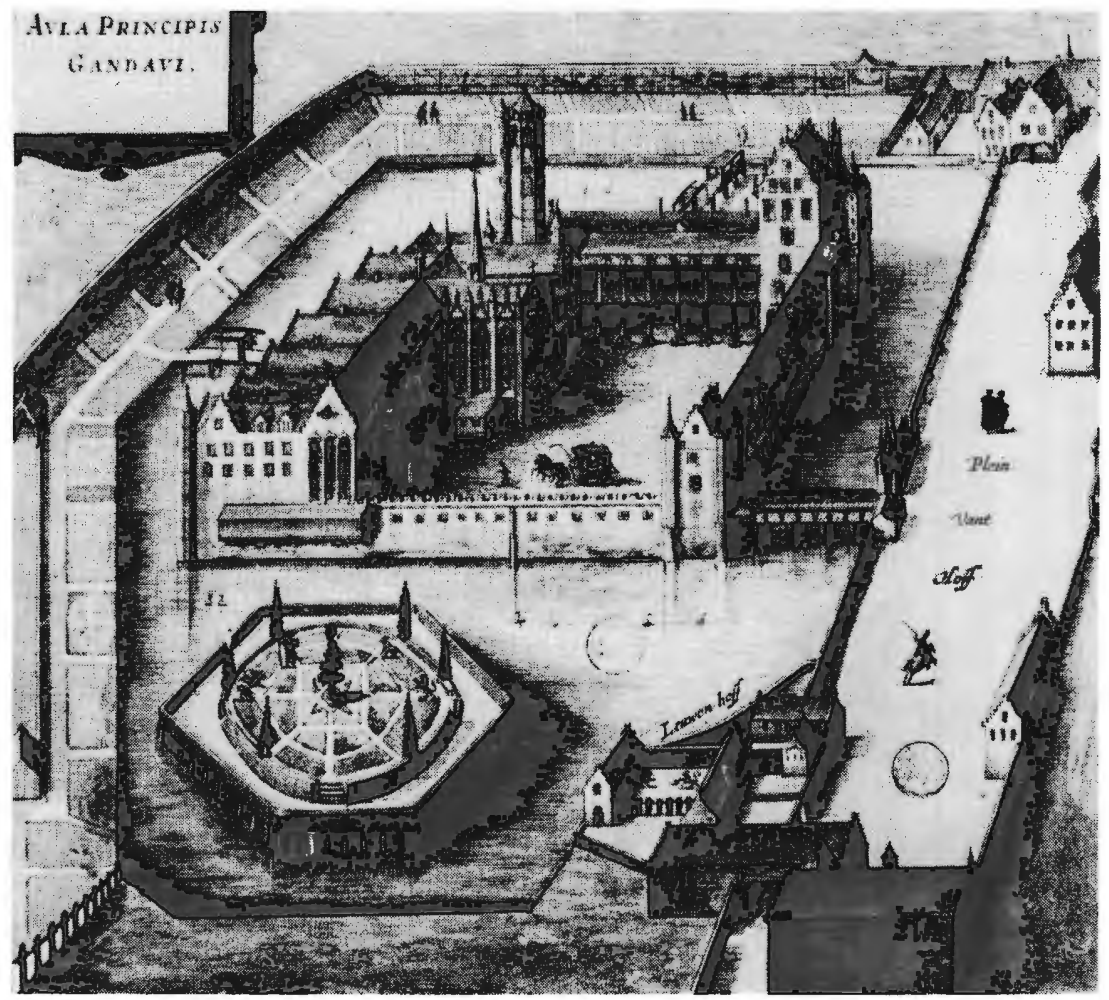

Afb. 3: De voorstelling van de 'Aula Principis Gandavi' in de Flandria Illustrata van Antonius Sanderus, 1641 (Foto Stadsarchief, Gent)

54 Ze wijken in belangrijke mate van wat tot voor 2000 over het Prinsenhof verscheen. Zie bijvoorbeeld: VAN WESEMAEL, M., 't Gewezen Prinsenhof van Gent, zijn tijd, zijn groei, zijn streven, zijn tijdgenoten wel bekend, in woord en beeld beschreven', in: Ghendtsche Tijdinghen, Gent, 1980, jg. 9 nr. 1, p. 222-234 en p. 264-285. 


\section{MARIE CHRISTINE LALEMAN}

bewaard ${ }^{55}$. De gebruikte materialen wijzen op diverse bouwcampagnes of herstellingen, onder meer in 1443-1444. Aan de zuidzijde was de omheiningsmuur omgeven door een grachtje van ca. $3 \mathrm{~m}$ breed.

De toegang tot het hof was op twee plaatsen georganiseerd. Vanuit de stad moest men voorbij het Gravensteen, via de Keizersdreve of het huidige Gewad naar een eerste poort, de zuidpoort ${ }^{56}$ die bij de zuidelijke omheiningsmuur aansloot (afb. 5). Ten oosten gaf een nevenpoort uit op het Hof van Auxy, een adellijk verblijf dat als satelliet bij het vorstelijke hof ontstond en waarvan de hele configuratie terug te vinden is in het perceel dat thans door theater De Tinnen Pot wordt ingenomen. Reeds in 1341 maakte dit terrein deel uit van het landcijnzenbezit van de Groene Briel. Na de overname van het Hof ten Walle

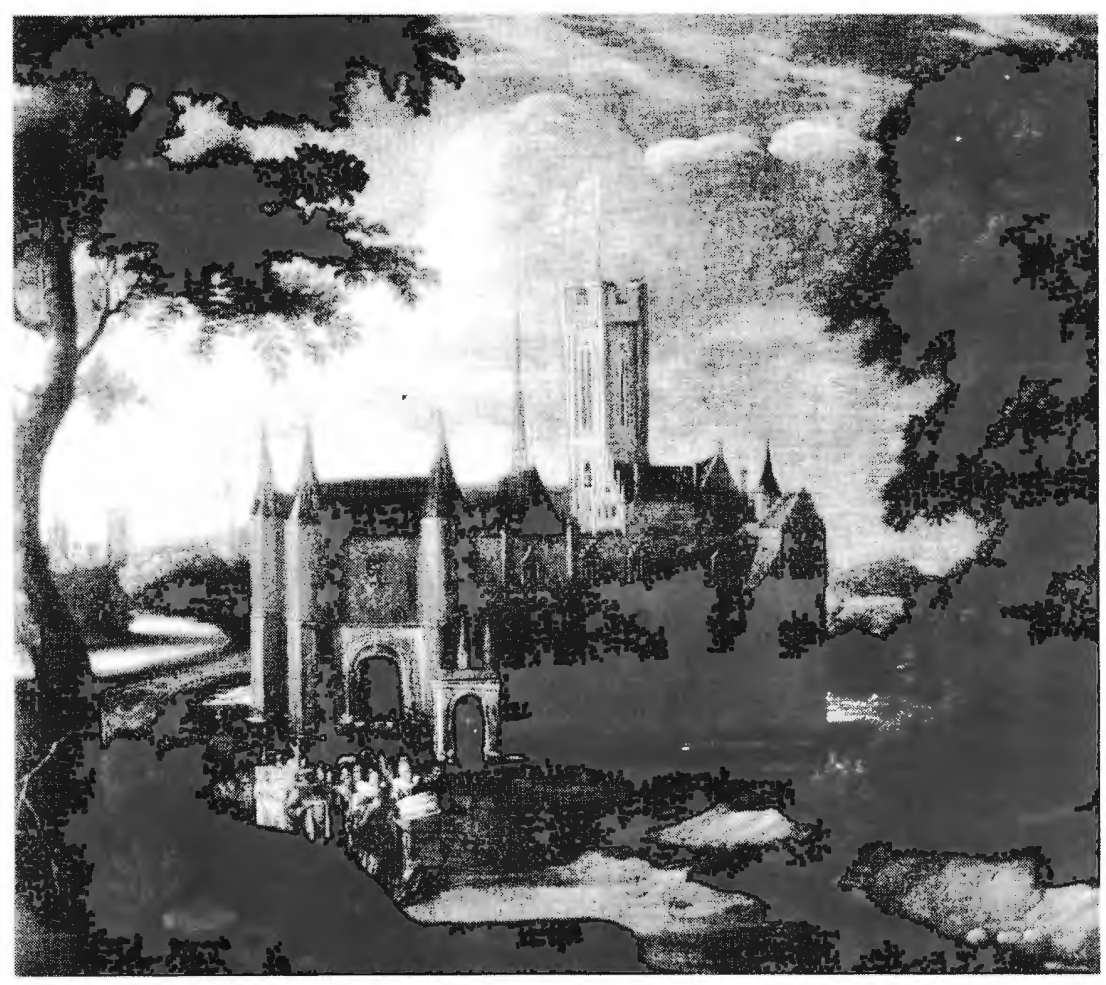

Afb. 4: Gezicht op de residentie van het Hof ten Walle, vanaf de oostzijde naar de hoofdpoort en het kerneiland, anoniem schilderij, 17de eeuw (Foto Bijlokemuseum, Gent

55 Zie ook: LALEMAN, M.C. \& RAVESCHOT, P., 'Prinsenhof-Bachtenwalle', in: Stadsarcheologie. Bodem en monument in Gent, Gent, 1990, jg. 14 nr. 2, p. 53-54; LIEVOIS, D., 'Op bezoek....', p. 89-91.

56 Zie ook: LIEVOIS, D., 'Op bezoek...', p. 91. 


\section{HET PRINSELIJK HOF TEN WALLE IN GENT}

door de graven van Vlaanderen stonden daar een grote love en drie kleinere huizen. Tussen 1425 en 1442 werd die grote love verworven door meester Goesen de Wilde, voorzitter van de Raad van Vlaanderen. Na zijn onthoofding werd zijn broer Jan de Wilde eigenaar die dit hof verkocht aan Jan van Auxy, kamerheer van hertog Karel de Stoute. Ook de hele verdere geschiedenis van la maison gisant lez et au plus près de la porte et court de le Walle of het huis an de vorster poorte van Sanderswalle kan via het recente onderzoek worden samengesteld ${ }^{57}$.

Meer noordelijk bevond zich een tweede poort, de zogenoemde middenpoort ${ }^{58}$, met ten oosten een kleine poortkapel en wat meer noordelijk de paardenstallen ${ }^{59}$ en met daartegenover de leeuwenhof ${ }^{60}$. De poortkapel, ook aangeduid als la chapelle en la basse court of la chapelle du commun, werd grondig verbouwd in 1467-1469. Een beschrijving van 1475 duidt ze aan als een eenbeukige ruimte van 11 bij $4 \mathrm{~m}$, bekroond door een dakruiter. Volgens Alfons Van Werveke was ze toegewijd aan Sint-Wido (Gewijde, Guido, Guillaume $)^{61}$. Het voorhof van de hertogelijke residentie was verder omringd door tal van andere nutsgebouwen die het leven van de hertogelijke familie moesten mogelijk maken. Dit voorhof, wellicht een 14de-eeuwse uitbreiding van de oude Wal, was nodig geworden toen het vermoedelijk vroegere voorhof tot de eigenlijke residentie werd uitgebouwd, een ontwikkelingsproces dat in heel wat 14de-eeuwse adellijke en vorstelijke verblijven werd vastgesteld.

Ten noorden van het voorhof bevindt zich de nog bestaande noordpoort (afb. 6), sedert 1899 Donkere Poort genoemd ${ }^{62}$ en langsheen de Lieve uitgevend op de laatmiddeleeuwse stadsvest. Of men deze poort enkel als secundair of achteruitgang mag beschouwen, is niet zeker. De poortconstructie was zeer opvallend uitgewerkt en bekroond met torentjes, een uiterlijk kenmerk dat de aanwezigheid van het vorstelijke hof moest aanwijzen.

Op grond van de huidige inzichten kan gesteld dat het kerneiland van de Bourgondische residentie ontstaan is uit het voorhof van de oudere motte. Het 17de-eeuwse beeldmateriaal (afb. 1, 3 en 4) toont een amalgaan van verschillende gebouwen, wat wijst op een organische groei in diverse etappen. Het was geen volledig gesloten kasteel. De drie hoofdvleugels gaven uit op een geplaveid binnenplein en waren gericht naar ten zuiden gelegen tuinen en

57 Met dank aan historicus Daniel Lievois voor deze gegevens.

58 Zie ook: LIEVOIS, D., 'Op bezoek...', p. 92-94.

59 Zie ook: LIEVOIS, D., 'Op bezoek...', p. 94-97.

60 Zie ook: LIEVOIS, D., 'Op bezoek...', p. 98-117.

61 Stadsarchief, Gent, Nota's Van Werveke, nr. 247, Prinsenhof. Met dank aan historicus Daniel Lievois voor deze mededeling.

62 LAPORTE, D., 'De Donkere Poort, het behoud en de reparaties', in: LALEMAN, M.C. (dir.), 2000, p. 245-257. 


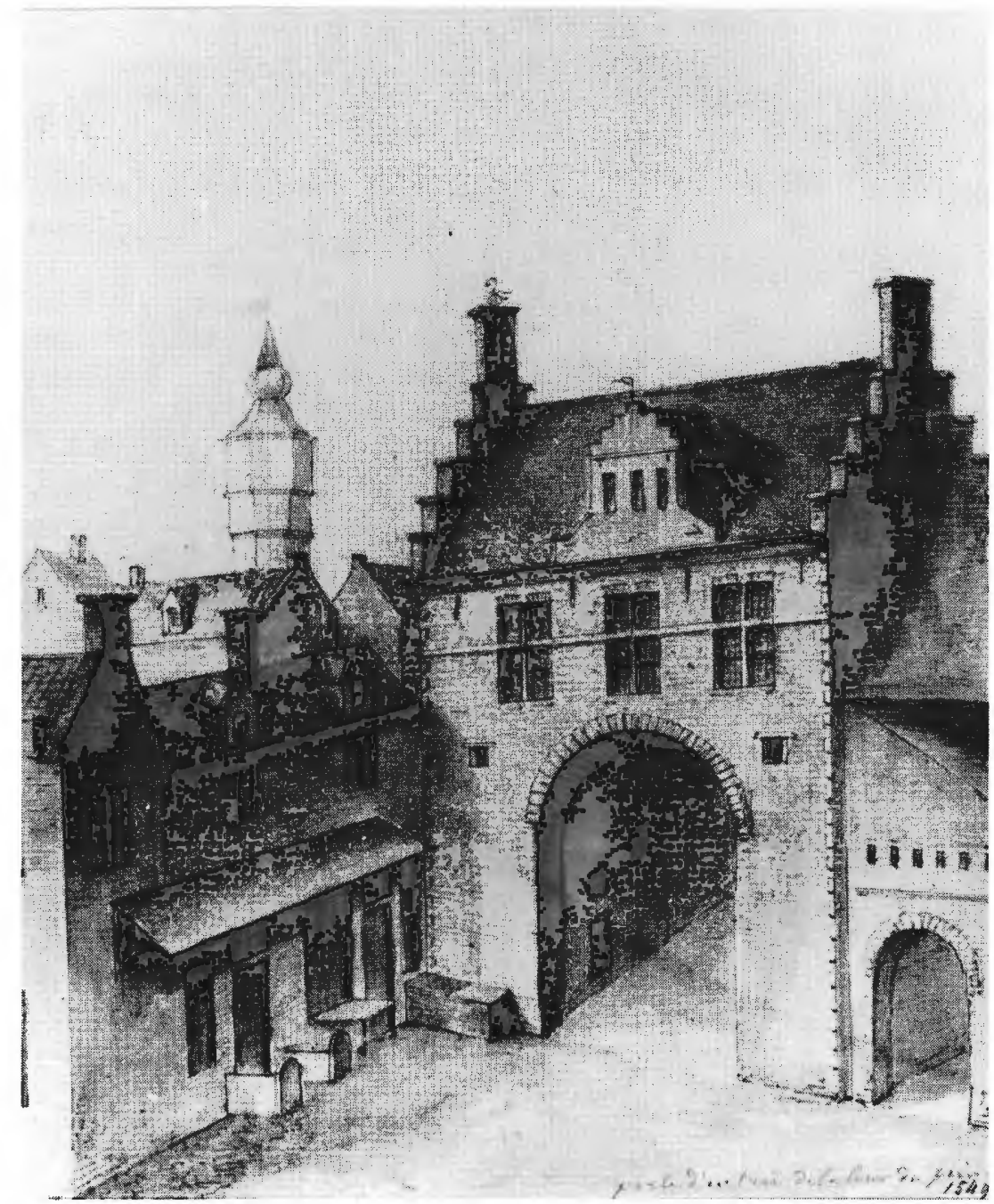

Afb. 5: De zuidpoort van het Prinsenhof in 1549 met ten westen twee winkeltjes en ten oosten de toegang tot het Hof van Auxy, verzameling Auguste Van Lokeren (Foto Handschriftenverzameling, Universiteit Gent) 


\section{HET PRINSELIJK HOF TEN WALLE IN GENT}

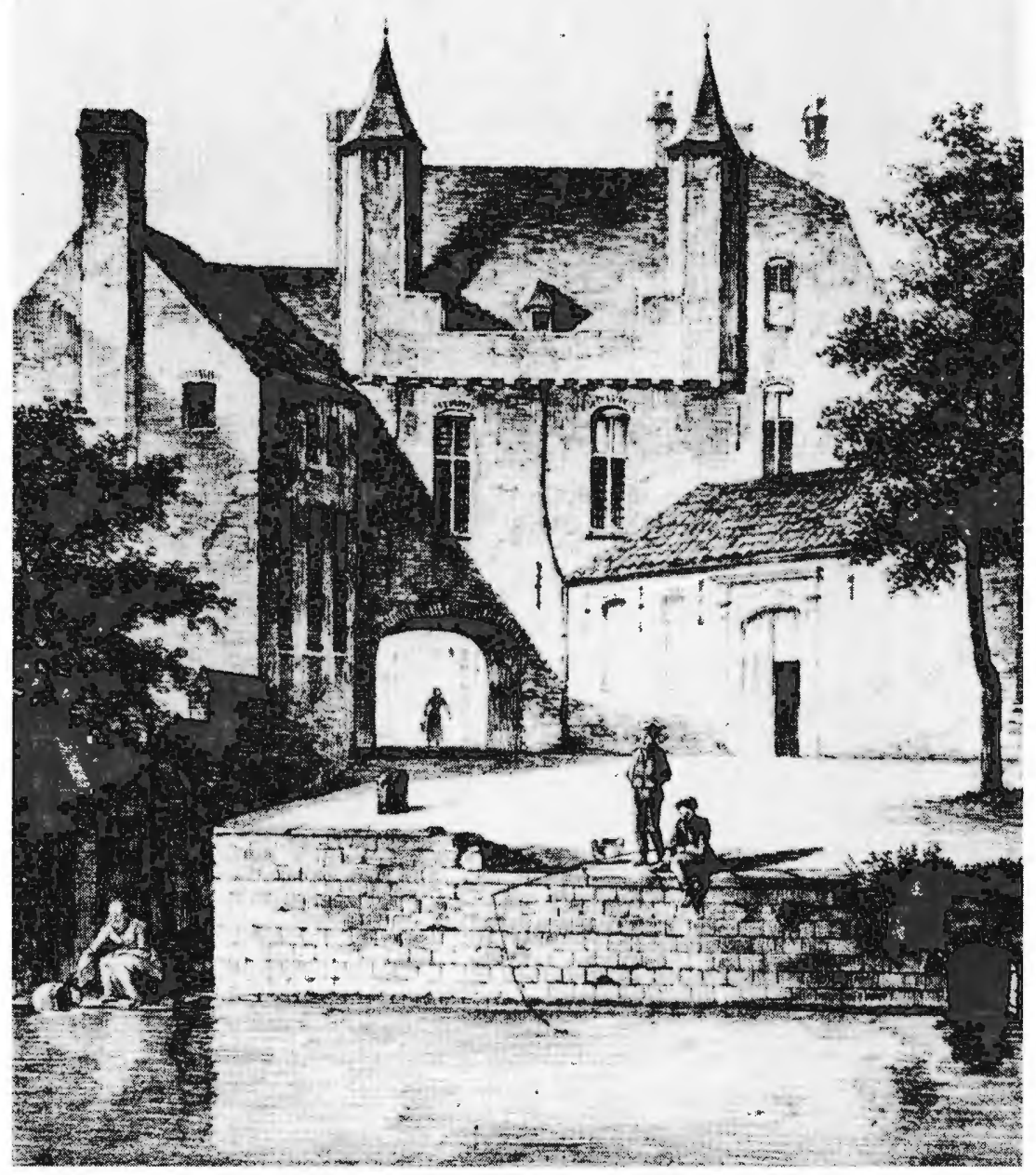

Afb. 6: Toegang tot het Prinsenhof in 1823: de zogenoemde Donkere Poort wordt voorgesteld met de originele flankeertorentjes en met een borstwering zonder kantelen, tekening C. de la Bariière en J.B. de Jonghe, gravure Dewasme \& Cie (Foto Stadsarchief, Gent) 


\section{MARIE CHRISTINE LALEMAN}
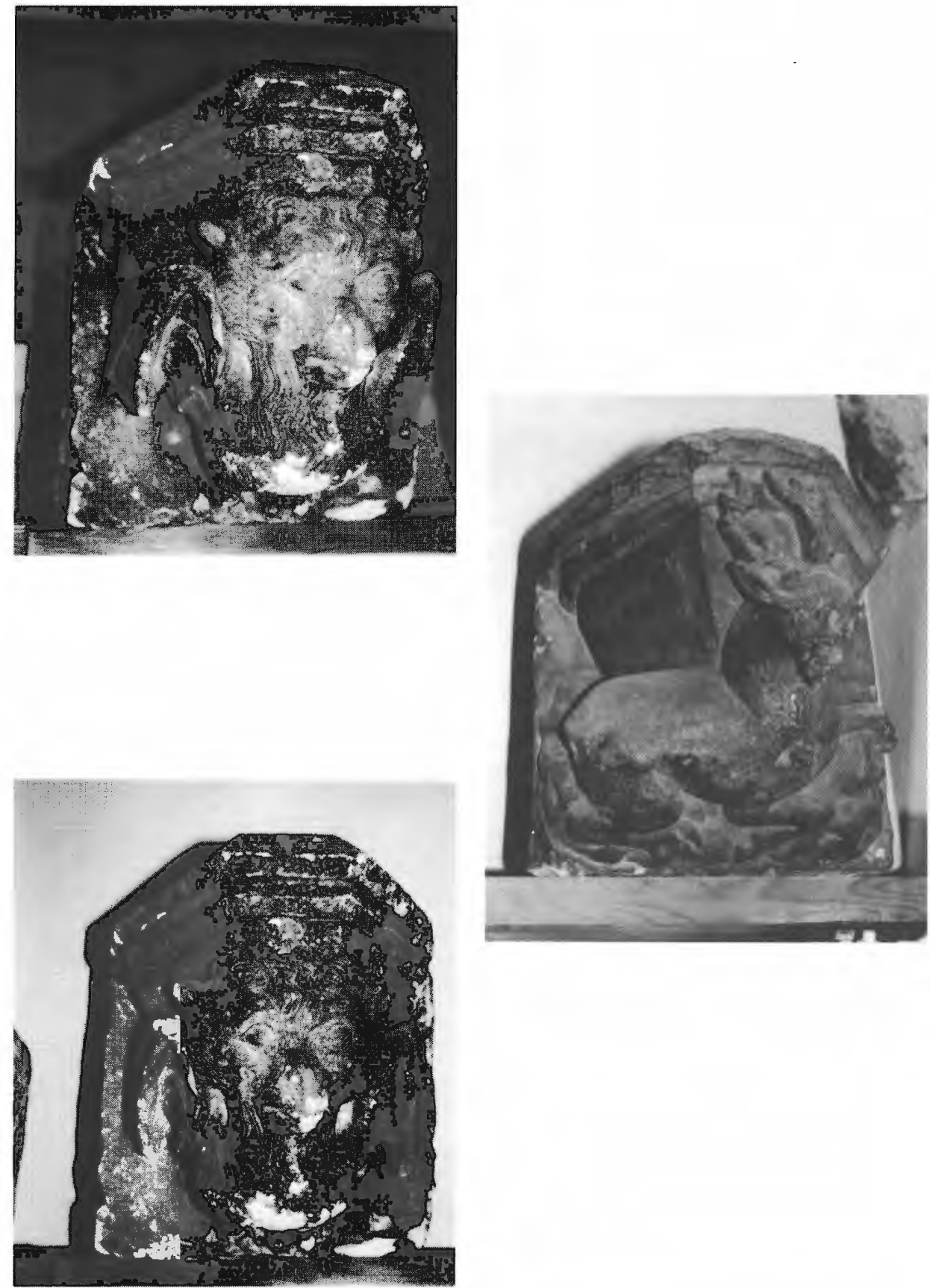

Afb. 7: Zwartverbrande kraagstenen in Lediaanse kalkzandsteen, afkomstig van de grote zaal en thans bewaard in het Museum van de Sint-Baafsabdij (Foto's Dienst Stadsarcheologie, Gent) 


\section{HET PRINSELIJK HOF TEN WALLE IN GENT}

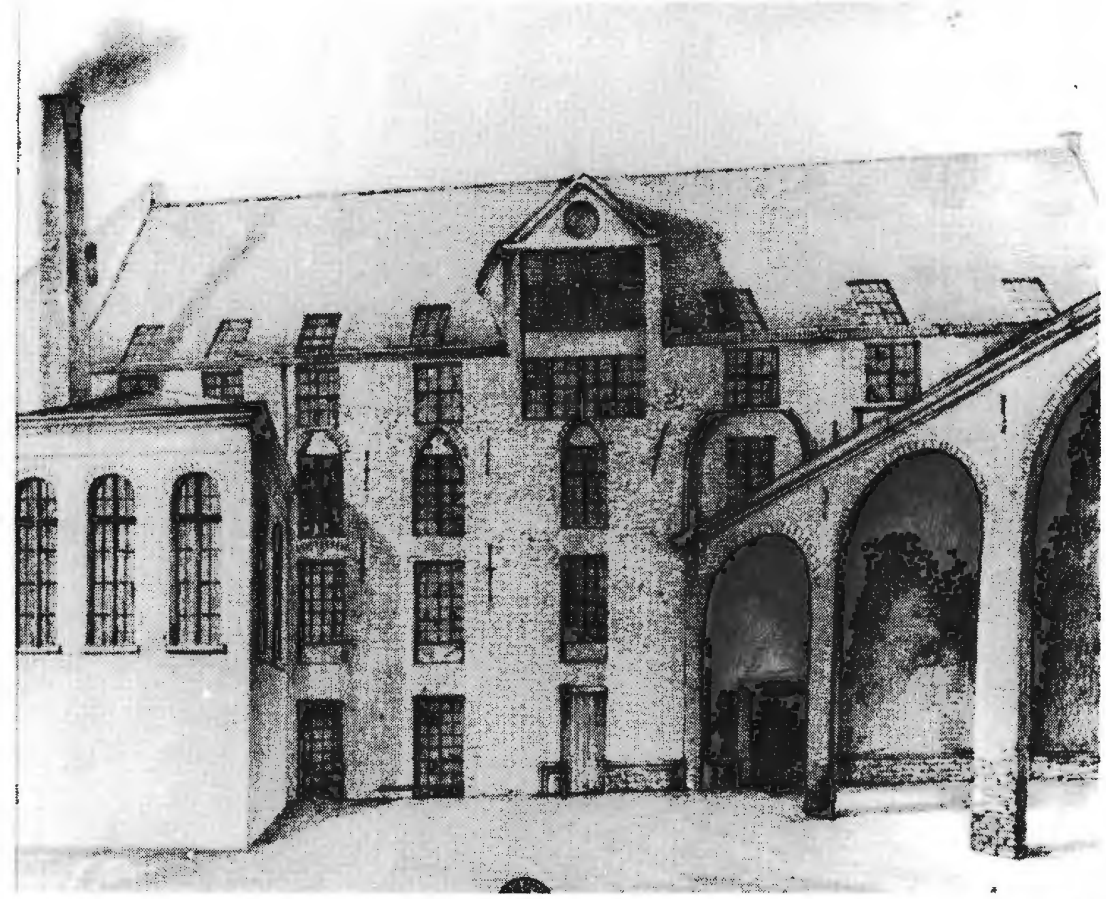

Afb. 8: De noordgevel van de grote zaal met aanpassingen uit de 18de en de 19 de eeuw, onder meer voor de toenmalige fabrieksfunctie, tekening Auguste Van Lokeren, 1835 (Foto Handschriftenverzameling Universiteit Gent)

weilanden. Een brug over de oostelijke slotgracht verbond het voorhof met een stoere poortconstructie. Het centrale volume was geflankeerd door vier ronde hoektorens ${ }^{63}$. De onderbouw met een parement van witte kalkzandsteen is mogelijk een restant van een 14de-eeuwse poortdonjon. Ook in de rekeningen van het hof wordt dit onderdeel van het complex als donjon aangeduid ${ }^{64}$. De donjon die in Laarne omstreeks 1360 werd opgetrokken, biedt een goede vergelijking. Deze poortdonjons uit de 14 de eeuw werden nog maar weinig bestudeerd en vertegenwoordigen een laatste fase in de ontwikkeling van de donjon als residentiële toren 65 . In een volgende ontwikkelingsfase verplaatste de woonfunctie zich naar andere gebouwen of vleugels rondom een bin-

63 Zie ook: LALEMAN, M.C., STOOPS, G. \& VAN DE WALLE, R., 'Prinsenhof', in: Stadsarcheologie. Bodem en monument in Gent, Gent, 1995, jg. 19 nr. 4, p. 43-45.

64 Zie ook: LIEVOIS, D., 'Op bezoek...', p. 137-139.

65 Zie ook: DOPERE, F. \& UBREGTS, W., 'La fin du donjon résidentiel dans le nord de la Belgique', in: Château Gaillard, Caen, 1990, nr. 14, p. 141-157. 


\section{MARIE CHRISTINE LALEMAN}

nenplein 66 . Voor een aantal bouwkundige details vindt men tevens parallellen bij de Hallepoort in Brussel die in de periode $1357-1363^{67}$ werd opgetrokken.

Tegenover de poorttoegang, aan de andere zijde van het binnenplein, lag de grote zaal. De zaal of aula was een essentieel onderdeel van een adellijk of vorstelijk verblijf ${ }^{68}$. Het was de ontvangstruimte voor veel officiële aangelegenheden. Dit hoge eenbeukige zaalgebouw was verlicht door spitsbogige vensters. Het houten beplankt gewelf werd opgevangen door gepolychromeerde figuratieve kraagstenen met voorstelling van fabelwezens ${ }^{69}$ (afb. 7). Deze bouwsculpturen werden vervaardigd van Lediaanse kalkzandsteen ${ }^{70} \mathrm{De}$ sculpturale uitwerking is nogal vol en hoewel verfijnd, missen we de geraffineerde uitwerking van de latere $15 \mathrm{de}$ en de $16 \mathrm{de}$ eeuw. Typologisch lijkt een datering in de late 14de eeuw mogelijk. Dit geldt ook voor de profilering van teruggevonden bouwonderdelen. De kraagstenen werden gerecupereerd toen de grote zaal (afb. 8), dan in gebruik als katoenfabriek, door een brand op 29 januari 1834 werd vernietigd ${ }^{71}$.

Ten oosten van de zaal lag de antisale, of de antichambre, de kamer of came$r a$ die sinds de laat-Karolingische tijd steevast bij de grote zaal aansloot. Dit was het minder officiële vertrek waar de heer een beperkter aantal gasten of een kleinere delegatie kon ontvangen en er met hen kon eten. Voor de bouwkundige relicten van de antisale, die in situ konden worden geregistreerd, is een datering in de latere 14 de eeuw niet uit te sluiten.

66 Tot de beter bestudeerde exemplaren, als onderdeel van een groter geheel, behoort de poortdonjon van het Brabantse Londerzeel, zie: DEWILDE, M., e.a., De 'Burcht' te Londerzeel. Bewoningsgeschiedenis van een motte en een bakstenen kasteel, Zellik, 1994.

67 de WAHA, M. \& DE POORTER, A., 'Een historisch symbool te Brussel, de Hallepoort', in: Resultaten van de eerste archeologische opgravingen in het Gewest, Brussel, 1993, p. 30-35.

68 Zie ook: RENOUX, A., “"Aux marches du palais”, des mots, des concepts et des réalités fonctionelles et structurelles', in: RENOUX, A. (dir), “Aux marches du palais". Que'est-ce qu'un palais médiéval, Le Mans, 2001, p. 9-20.

69 Zie ook het getuigenis van A. Van Lokeren in: VAN LOKEREN, A., La Cour..., p. 42. Vergelijkbare monumentale sculptuur uit de late 14de en het begin van de 15de eeuw wordt ook behandeld door BODIAUX, C., 'De gebeeldhouwde zwikken in het koor. Enkele iconografische thema's en stijlkenmerken', in: Monumenten en Landschappen, Brussel, 2000, jg. 19 nr. 5, p. 49-62.

70 Identificatie door Prof. Dr. R. Nys, Laboratorium voor Petrografie van de Universiteit Gent.

71 DESTANBERG, D., Gent sedert 181. Voornaamste gebeurtenissen, Gent, 1903, p. 118-119. 


\section{HET PRINSELIJK HOF TEN WALLE IN GENT}

Bij de zaal en de antisale hoorde een derde belangrijk component, met name de kapel $^{72}$. Op de 17de-eeuwse iconografische bronnen is ze oost-west-georiënteerd. Ze telde drie traveeën en had een vijfzijdige, weinig geprononceerde koorsluiting of apsis. Alleen de zuidgevel en de apsis waren niet ingebouwd. Een dubbele toegang verbond de kapel zowel met de zaal als met de antisale. Ten noorden van de kapel lag het oratorium, de privé-bidplaats van de heer ${ }^{73}$.

De noordelijke vleugel bevatte de appartementen van de hertog en de hertogin. Volgens de bewaard gebleven rekeningen werden die na een brand in 1419 volledig heropgebouwd tussen 1421 en $1429^{74}$. In de geschreven bronnen wordt dit het 'nieuwe huis' genoemd. De benedenverdieping had vier kamers die op het binnenplein uitgaven. Op de verdieping erboven was de middelste kamer dubbel groot en waren er bijgevolg slechts drie ruimten. Hoe de tweede verdieping was ingericht, komt in de geschreven bronnen niet aan

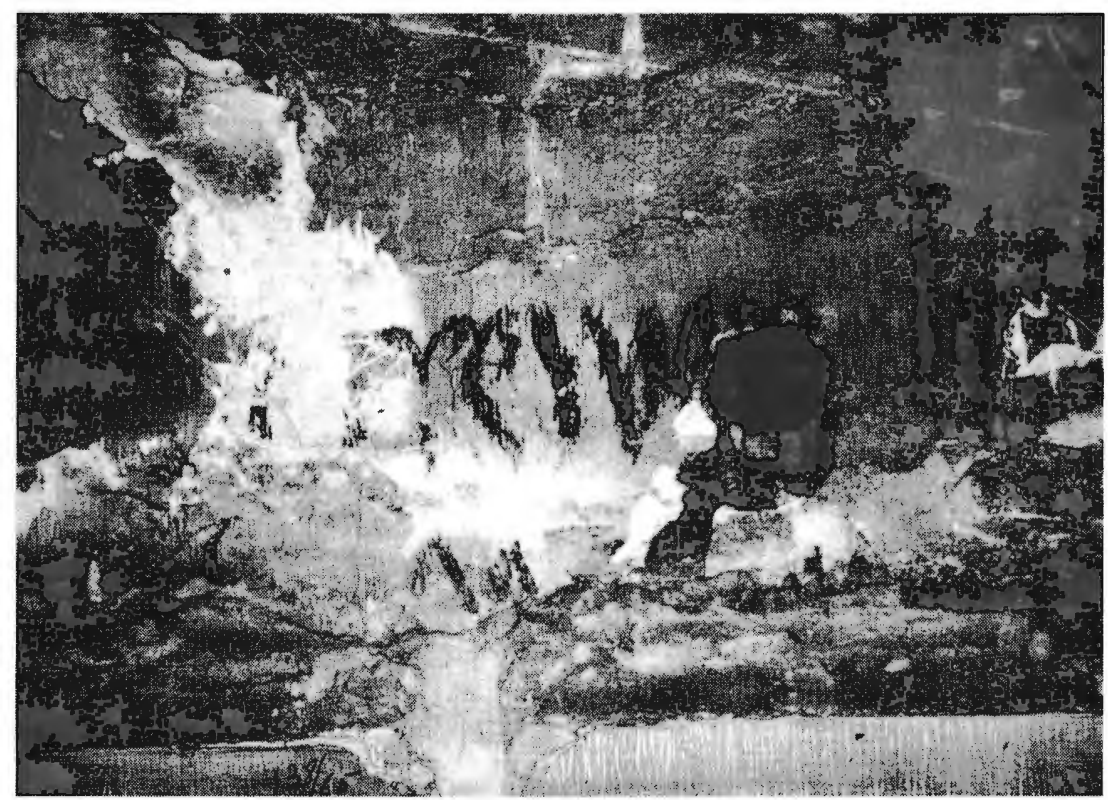

Afb. 9: Sporen van wandafwerking met tekst ontdekt op de wand in een kamer van de noordvleugel, thans Sanderswal 6 (Foto Dienst Stadsarcheologie, Gent)

72 Zie ook: LIEVOIS, D., 'Op bezoek...', p. 142-147.

73 Uitgebreide toelichtingen over de kapellen en de oratorii in de residenties van Gent, Brugge en Lille bij DE JONGE, K., 'Bourgondische residenties...', p. 93-134.

74 BOONE, M., Op. cit., 1989; LIEVOIS, D., 'Op bezoek...', p. 151-156. 


\section{MARIE CHRISTINE LALEMAN}

bod. Wel zijn er talrijke gegevens bekend over details van de interieurinrichting en over de kleurrijke afwerking van leiendak en gevels. Het nieuwe huis was volledig piekfijn uitgerust toen Filips de Goede en Isabella van Portugal zich hier in 1430 na hun huwelijk in Brugge kwamen terugtrekken. Er waren drie bouwlagen onder een zadeldak. De huidige perceelsstructuur van de woningen aan de zuidzijde van de Sanderswal(straat) weerspiegelt nog steeds de kamerindeling van de noordvleugel. Dat de hele structuur en tal van details nog in situ aanwezig waren, bewees het archeologisch onderzoek dat onder meer in Sanderswal 6, voorafgaand aan de jongste renovatie, kon worden uitgevoerd. De gelijkgrondse en wellicht ook de hogere kamers waren overdekt door houten balkenzolderingen. De moerbalken waren ca. $9 \mathrm{~m}$ lang en hadden een doorsnede van 45 bij $36 \mathrm{~cm}$. Ze waren vermoedelijk met witte kalkverf afgewerkt, terwijl de kinderbalken aan de onder- en de zijkanten voorzien waren van rode kalkverf. Tussen de kinderbalken werd een pleisterlaag teruggevonden op rinkellatjes die op de onderzijde van de plankenvloer (planken van 30 tot $40 \mathrm{~cm}$ breed) van de bovenliggende verdieping waren bevestigd. Deze pleisterlaag bevatte leem, gewapend met stro. De afwerking bestond uit een witte kalklaag. Bovendien werden er op de wanden van de huizen Sanderswal 5 en 6 sporen van wanddecoratie opgemerkt. De letters en de florale motieven verraden een laatgotische traditie (afb. 9). De fragmenten waren evenwel te beperkt om de teksten of namen te kunnen achterhalen ${ }^{75}$. Het zouden bijvoorbeeld de namen of lijfspreuken van hertoginnen kunnen zijn. Aan de zuidkant was de noordvleugel geflankeerd door een open galerij die in de 15de eeuw drie bouwlagen had. Er werden sporen van de indeling en de stenen gewelven teruggevonden. De grote galerij was een essentieel onderdeel van de Bourgondische hofresidenties in de Lage Landen ${ }^{76}$. Deze staatsiegalerij deed niet zelden dienst als grote zaal, wat in Gent ook het geval was, onder meer wanneer de Gentenaren in 1540 hun sententie van Keizer Karel ontvingen. De bovenverdieping had voornamelijk een communicatie- en circulatiefunctie.

De materiële sporen wezen aan dat de noordvleugel (afb. 10) aanvankelijk korter was en naderhand in westelijke richting werd uitgebreid. Dit had duidelijk te maken met een bouwcampagne aan de hertogelijke appartementen. Door die uitbreiding werd de noordvleugel verbonden met de belvédère, een polygonale toren die hoog boven alle gebouwen van de residentie oprees (afb. 3 en 4). Op grond van alle beschikbare materiële, geschreven en iconografische bronnen kan hij nader geduid worden ${ }^{77}$. Deze toren werd in 1444-

75 Typologisch is er een verwantschap met de tekst die voorkomt op de kamerwand in het schilderij van Jan van Eyck dat het bruidspaar Arnolfini voorstelt en waaruit blijkt dat de schilder dit werk vervaardigde in 1434 .

76 DE JONGE, K., 'Leven...', p. 71.

77 LIEVOIS, D., 'Op bezoek...', p. 148-151. 


\section{HET PRINSELIJK HOF TEN WALLE IN GENT}

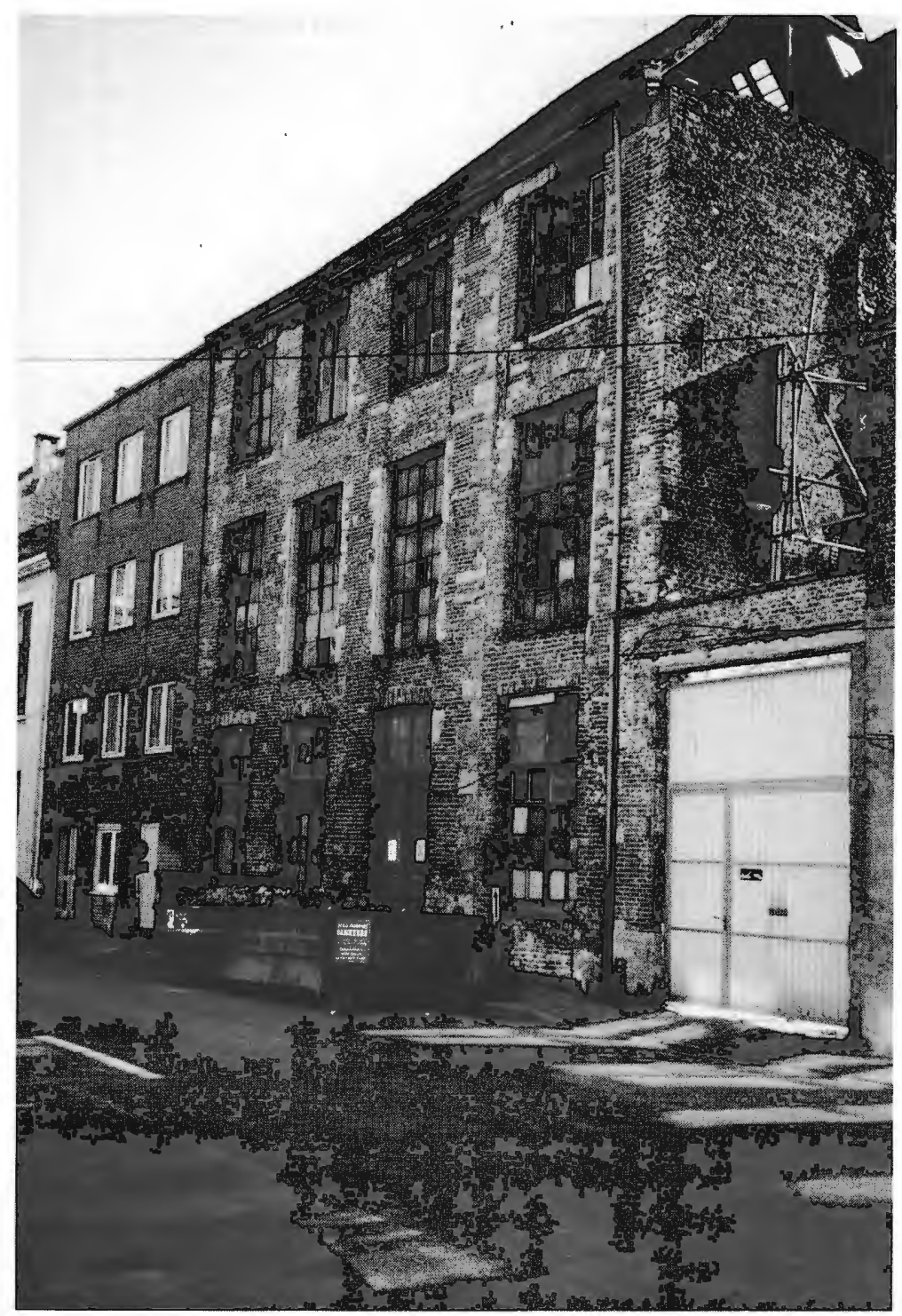

Afb. 10: In het huis Sanderswal 8 was de structuur van de noordvleugel het best bewaard tot aan de instorting van dit pand in 1993: natuurstenen hoekblokken geven de bouwnaad aan tussen de noordvleugel en de latere westelijke uitbreiding met één travee (Foto M. Helskens, Gent) 


\section{MARIE CHRISTINE LALEMAN}

1445 gebouwd met witte kalkzandsteen en baksteen. Aan de zuidwestkant was er een traptoren. De verschillende niveaus waren door horizontale lijsten gemarkeerd. De verdiepingen waren overwelfd. De gewelfsleutels toonden het wapenschild en de wapenspreuk van Filips de Goede. De kraagstenen, waarop de gewelfribben rustten, waren gedecoreerd met de Bourgondische vuurslag. Het hoogste niveau werd door smalle vensters van witte natuursteen met maaswerkverdeling doorbroken. De bekroning omvatte ook een borstwering die bovenaan niet horizontaal, maar in verschillende hoogtes eindigde, waarachter zich dan een dak verschool. Op de hoeken waren er waterspuwers. Dergelijke torens waren zeer courant in de 15de eeuw en kwamen ook bij particuliere huizen in de stad voor. Zowel in Gent ${ }^{78}$ als in Brugge ${ }^{79}$ en Antwerpen ${ }^{80}$ zijn er talrijke voorbeelden bekend. Over hun functie werd al heel wat discussie gevoerd. Zo zouden ze voor branddetectie en als uitkijkpost voor schepen hebben gediend. Veel logischer is evenwel de symbolische functie van macht en uitstraling. Die van het Hof ten Walle was niet toevallig een van de grootste, hoogste en meest versierde. Het was de Landmark van het hertogelijke hof dat van ver kon worden herkend. Ook het Brugse Prinsenhof had bij de galerij een hoge uitkijktoren uit de eerste helft van de 15 de eeuw.

De bewaard gebleven geschreven bronnen geven aan dat het hertogelijke appartement geregeld werd heringericht. Dit was onder meer het geval voor Filips de Goede in 1444-1445, toen er onder meer een pale werd geïnstalleerd ${ }^{81}$. Dit is tot op heden het vroegst bekende voorbeeld van een dergelijke

78 Enkele voorbeelden bij: HEINS, A., 'Une maison gantoise. Ses transformations su XVe au XVIIIe siècle', in: Bulletin de la Société d'Histoire et d'Archéologie de Gand, Gand, 1904, p. 133 e.v.; LAPORTE, D., 'De Lievekom te Gent. Bouwgeschiedenis', in: Stadsarcheologie, Gent, 1982, jg. 6 nr. 3, p. 19; DESEYN, G., Gids voor oud Gent, Antwerpen, 1984, p. 26, p. 83, p. 96, p. 107-108 en p. 433-434; EVERAERT, G. \& VAN DOORNE, G., Gent steenrijk, Gent, 1985, p.39, p. 63, p.71 en p. 77; DESEYN, G., 'Langemunt 22', in: Stadsarcheologie. Bodem en monument in Gent, Gent, 1986, jg 10 nr. 1, p. 40-41..

79 Zie bijvoorbeeld: DEVLIEGHER, L., De huizen te Brugge, (Kunstpatrimonium van West-Vlaanderen, nr. 2-3), Brugge, 1975, p. XIV; BEERNAERT, B., CONSTANDT, L. \& ESTHER, J.P., Het Hof van Gistel. Geschiedenis en restauratie van een herenhuis in Brugge, Brugge, 1983, p. 30-34.

80 Zie bijvoorbeeld: DERYCKE, I., 'Korte historische schets van het onderzoeksgebied 'Guldenberg', in: Blik in de bodem. Recent stadsarcheologisch onderzoek in Antwerpen, Antwerpen, 1992, p. 51-52.

81 LIEVOIS, D., 'Op bezoek...', p. 167-169. 


\section{HET PRINSELIJK HOF TEN WALLE IN GENT}

kacheloven in de Lage Landen ${ }^{82}$. Voor de wanden leverde Gossuin le pottre uit de parochie van Stekene vierenzestig vierkante reliëftegels, in de rekeningen 'potten' geheten. Ze waren versierd met de Bourgondische vuurslag, de wapentekens en de wapenspreuk van de hertog. De kachelconstructie was voorts afgewerkt met witte Brabantse kalkzandsteen. In 1468 werden de hertogelijke appartementen grondig aangepakt voor de komst van Karel de Stoute en Margaretha van York, na hun huwelijk in Damme. De grote kamer van de hertog kreeg nieuwe moer- en kinderbalken, evenals een lambrizering. De kamers van de hertogin, aan het andere eind van de vleugel, werden voorzien van een pale en dienden, op nadrukkelijke vraag van de hertogin, volledig herzien te worden inzake hygiëne ${ }^{83}$. Dit was voor haar één van de meest negatieve punten van het Gentse huis.

Ook ten tijde van Karel V werd het hertogelijke appartement grondig heringericht. Een balkzool met leeuwenkop die in het pand Sanderswal 8 werd aangetrofen, toont heel wat gelijkenissen met de van ringen voorziene leeuwenkoppen die in 1526 in opdracht van Karel V in de buitengevel van zijn paleis naast het Alhambra in Granada (Spanje) werden aangebracht.

De oostvleugel (afb. 11), die tot voor kort in belangrijke mate bewaard bleef aan de achterzijde van de huizen Prinsenhof 105-109, had voornamelijk een woonfunctie waar hofpersoneel kon verblijven. De eerder smalle vleugel had drie bouwlagen, waarvan de bovenste een hoge zolderverdieping was (afb. 12). De houten portiekstructuur, waarvan heel wat sporen tot voor kort in situ bewaard bleven, laat vermoeden dat die oostvleugel in de 15de eeuw werd opgetrokken. Dergelijke portiekstructuren waren in de 15 de eeuw heel courant in Gent. Het Vleeshuis aan de Groentenmarkt, het Toreken aan de

82 Tot op heden werden in de Prinsenhofsite nog geen fragmenten van kacheltegels teruggevonden zoals dit op andere plaatsen het geval is, zie: DUBBE, B., De kacheloven in onze gewesten, Lochem, 1966; GEBHARD, T., Kachelöfen: Mittelpunkt häuslichen Lebens. Entwicklung, Form, Technik, München, 1980; X., Thuis in de late middeleeuwen. Het Nederlands burgerinterieur 1400-1315, Zwolle, 1980, p 51 en p. 95; TRIMPE BURGER, J.A., 'Een kacheloven uit omstreeks 1470 te West-Souburg op Walcheren', in: Liber castellorum. 40 variaties op het thema kasteel, Zutphen, 1981, p. 354-359; ZANTKUYL, H.J., De warmte beschouwd, (Bouwen in Amsterdam, nr. 37), Amsterdam, 1982, s. p. In Gent werd er tot nog toe slechts één kacheltegel uit archeologische context bestudeerd, zie: ADRIAEN, M. \& RAVESCHOT, P., 'Onderbergen 4', in: Stadsarcheologie, Gent, 1984, jg. 8 nr. 1, p. 69-70. Het stuk is wellicht afkomstig van een 'pale' in het Hof van Kleef. Het Bourgondische paleis op die plaats, ook bekend als het Hof van Ravenstein, was van 1417 tot 1609 in handen van de familie Van Kleef.

83 De gegevens over op Engelse gewoonten geïnspireerde voorzieningen zijn heel wat ouder dan traditioneel wordt aangenomen, zie voor de algemene context: LAMARCQ, D., Het latrinaire gebeuren, (Stichting Mens en Kultuur), Gent, 1993. 


\section{MARIE CHRISTINE LALEMAN}

Vrijdagmarkt en de 15 de-eeuwse fase van zowel De Ingel aan de Graslei ${ }^{84}$ als De Spiegel aan het Goudenleeuwplein ${ }^{85}$ zijn andere Gentse voorbeelden. De moerbalken worden door korbelen met muurstijlen verbonden. De verschil-

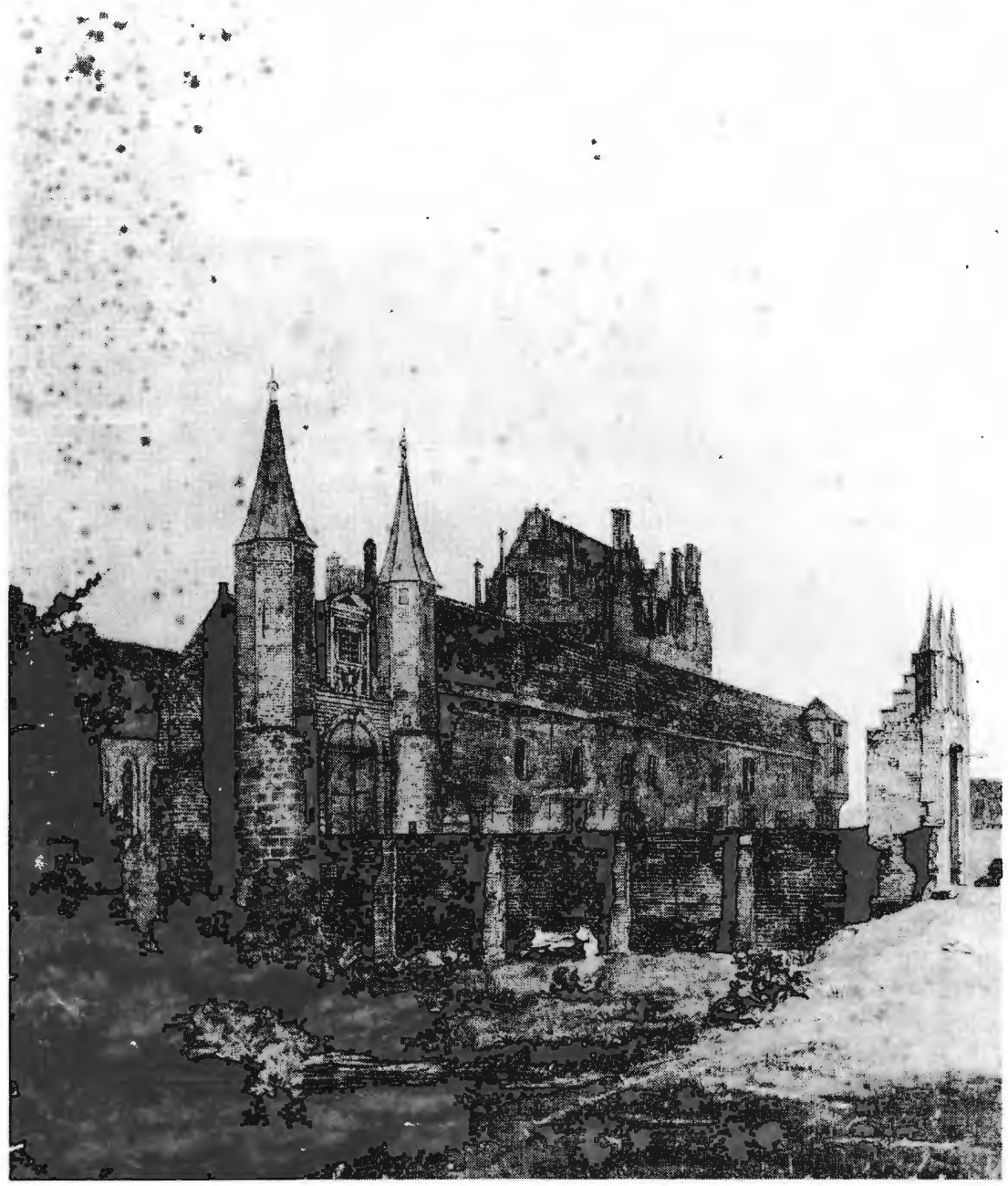

Afb. 11: De hoofdpoort, de burg over de oostelijke slotgracht, de oostvleugel en daarachter de 'tour de la grande montée', detail uit een aquarel van Jacques Trachez, 1778 (Foto Stadsarchief, Gent)

84 EVERAERT, G., e.a., 'Het huis 'de Inghel' aan de Graslei te Gent', in: Handelingen der Maatschappij voor Geschiedenis en Oudheidkunde, Gent, 1995, nr. 49, p. 142-146.

85 BOUCQUET, D., e.a., 'Het huis De Spiegel aan het Goudenleeuwplein. Archeologisch en bouwhistorisch onderzoek', in: Stadsarcheologie. Bodem en monument in Gent, Gent, 1997, jg. 21 nr. 3-4, p.11-55. 


\section{HET PRINSELIJK HOF TEN WALLE IN GENT}

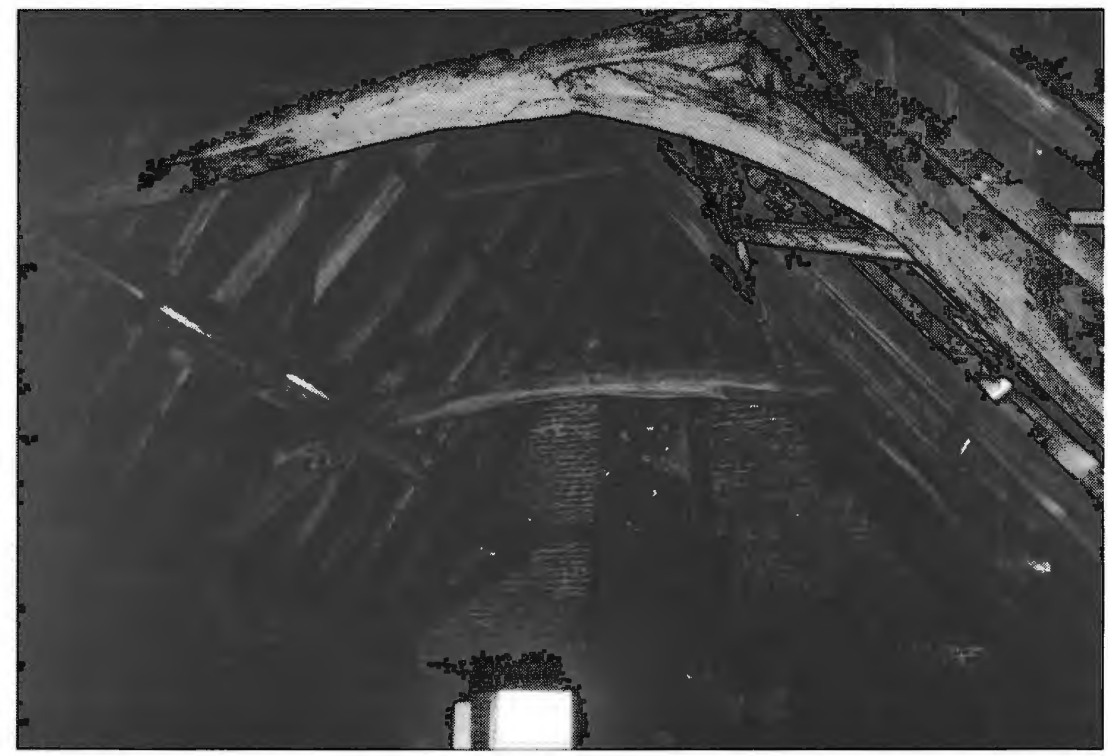

Afb. 12: De 15de-eeuwse dakconstructie van de oostvleugel, behouden in Prinsenhof 105 (Foto Dienst Stadsarcheologie, Gent)

lende niveaus waren door balkenzolderingen en houten vloeren van elkaar gescheiden. Verscheidene kinderbalken toonden nog sporen van alternerende rode en zwarte beschildering. Net zoals bij de noordvleugel waren heel wat venster- en deuropeningen segmentbogig afgewerkt. Het metselwerk getuigde voorts van een uiterst verzorgde afwerking.

In de oksel tussen noord- en oostvleugel stond een monumentaal gebouw, dat evenwel niet zo hoog was als de belvédère. Het bevatte een monumentale trap rondom een vierkante, massieve centrale spil - vandaar de naam tour de la grande montée. Vanuit dit gebouw was er toegang tot de galerij bij de noord vleugel en tot de oostvleugel ${ }^{86}$. Belangrijke relicten daarvan bleven bewaard in de panden Sanderswal 3 en 4. Een wellicht erg vergelijkbare structuur is de Tour Jean sans Peur in Paris, die in 1409-1411 werd gerealiseerd.

86 Daniel Lievois schrijft de bouw van deze toren toe aan Margaretha van Oostenrijk en dientengevolge zou hij deel uitmaken van een bouwcampagne uit het begin van de 16de eeuw, zie: LIEVOIS, D., 'Het Hof ten Walle...', p. 155-163. Het is duidelijk dat de geschreven bronnen verwijzen naar bouwwerkzaamheden aan de torenconstructie die op haar initiatief werden genomen, maar we vermoeden, op grond van enkele materiële indicaties, dat de torenconstructie reeds in de $15 \mathrm{de}$ eeuw bestond en wellicht in kern terug te voeren is tot de bouwcampagnes ten tijde van Filips de Goede. Anderzijds liet ook Maria van Hongarije daar later in de 16de eeuw werken uitvoeren: zie LIEVOIS, D., 'Het Hof ten Walle.'., p. 167-171. 


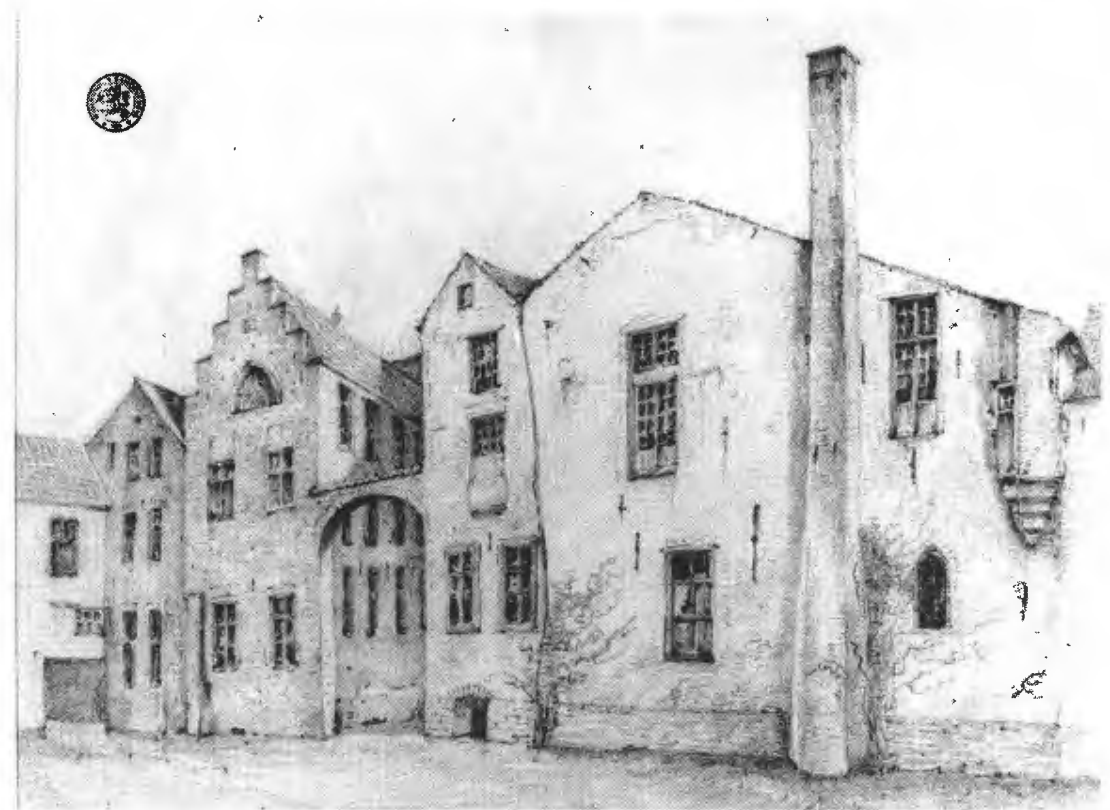

Afb. 13: Gezicht op de westkant van de residentie met de keukens, de stoven en andere nutsgebouwen, situatie in 1832, tekening Auguste Van Lokeren (Foto Handschriftenverzameling Universiteit Gent)

Tenslotte moet er nog iets gezegd over de westsector (afb .13), de gebouwen die ten westen van de zaal op het kerneiland waren opgetrokken en die talrijke nutsfuncties herbergden zoals de keukens, de baden, de wasserij. De geschreven bronnen wijzen uit dat ze herhaaldelijk werden verbouwd. Van dit gedeelte bleven ook weinig materiële relicten bewaard, of werden er als dusdanig herkend. De iconografische bronnen van de 17de-19de eeuw laten wel toe de algemene structuur, maar niet de chronologie te achterhalen. De westsector omvatte zeven onderscheiden delen. De twee meest zuidwestelijke bouwvolumes waren in de 17de eeuw al samengevoegd, met op de benedenverdieping een grote keuken. De ronde hoektoren die pas hoger aanzette, was zeker niet de geboorteplaats van Karel V zoals lange tijd werd geopperd.

De ruimtelijke opbouw van de residentie weerspiegelt de basis van het Bourgondische hofritueel ${ }^{87}$ zoals dit ook naar voren komt in diverse voorschriften die vooral onder hertog Karel de Stoute werden opgesteld, hoewel die geen expliciete bouwverordeningen omvatten. De inrichting van elke ruimte had te maken met zijn functie in het geheel van de hoforganisatie: privé, semi-privé of publiek. Het zou overigens interessant zijn om de archi- 


\section{HET PRINSELIJK HOF TEN WALLE IN GENT}

tectuur van het Prinsenhof te evalueren ten opzichte van andere stadspaleizen en buitenhuizen uit dezelfde tijd. Op dit ogenblik is dit onderwerp evenwel nauwelijks bestudeerd 88 .

Het recente projectonderzoek heeft aangetoond hoe men, door combinatie van alle bronnen, een inzicht kan verwerven in de aanleg en de organisatie van een herenresidentie zoals die voornamelijk in de latere 14de en de $15 \mathrm{de}$ eeuw tot stand kwam, maar ook nog in de $16 \mathrm{de}$ en de $17 \mathrm{de}$ eeuw verder werd uitgebouwd. Bijzonder verrijkend is tevens de link met de talrijke littekens, sporen of zelfs monumentale delen binnen de huidige Prinsenhofwijk, een uniek patrimonium dat elk jaar verder verloren gaat. De studie toonde ook aan met welke onmacht de personen werden geconfronteerd die zich sedert Auguste Van Lokeren in het tweede kwart van de 19 de eeuw $^{89}$ inzetten om deze site met zijn rijke verleden te herwaarderen en een nieuwe toekomst te geven ${ }^{90}$. Dit lukte evenwel nooit, ook niet in een meer recente tijd. De erfgoedzorg diende zich steeds te beperkten tot het archeologisch registreren van wat gedoemd is te verdwijnen. Wat liep er fout? Telkens weer merkt men constanten. Wie de materie ten gronde kent en zich ervoor inzet, vindt geen gehoor op het niveau waar over het erfgoed wordt beslist. Wie erover beslist, beschikt niet over de nodige kennis en neemt derhalve beslissingen die de degradatie bevorderen of neemt geen beslissingen die tot een herwaardering kunnen leiden. Kenmerkend is eveneens dat het erfgoedbeheer sedert de 19de eeuw niet opgewassen is voor een globale benadering van dergelijke grote sites met een gediversifieerd patrimonium en een thans erg versnipperde eigendomssituatie. De kennis over het geheel is ontstaan en gegroeid op basis van een interdisciplinaire benadering en is niet meer op te splitsen in stedelijke randsite, monumentaal patrimonium, historisch litteken of archeologisch erfgoed. Wanneer men die globale benadering terug wenst op te delen in vakjes die in se niets met een degelijk erfgoedbeheer te maken hebben, dan blijft er weinig over, een realiteit waarvan het Gentse Prinsenhof spijtig genoeg een toonbeeld is geworden.

88 VAN LOKEREN, A., 'La Cour...', p. 36-52; VAN LOKEREN, A., 'La Cour du Prince à Gand', in: Messager des sciences historiques, Gand, 1870, p. 255256.

89 Wat ook al werd aangestipt in de bijdrage van EVERAERT, G., 'Opvallend in het straatbeeld. Stadspaleizen in Gent', in: Toerisme Oost-Vlaanderen. Tijdschrift voor Recreatie en cultuur, Gent, 1998, jg. 47 nr. 5, p. 141-146. Zie ook: VAN TYGHEM, F., 'Dominanten in de middeleeuwse stadskern', in: POULAIN, N. (red.), Gent \& architectuur. Trots, schande en herwaardering in een overzicht, Brugge, 1985, p. 38-39.

90 EVERAERT, G., 'Pogingen tot herwaardering. Teloorgang en herwaardering van een wijk', in: LALEMAN, M.C. (dir.), Op cit. P. 237-244. LAPORTE, D., 'De Donkere Poort', p. 245-257; LAPORTE, D., 'De bescherming van het Prinsenhof: een veel te late interventie', in: LALEMAN, M.C. (dir.), 2000, p. 259-263. 
Essentieel is uiteraard de vraag wat men in Vlaanderen wil beschermen en hoe, welke criteria men daarbij wil hanteren, terwijl 'beschermen' uiteraard slechts één van de beleidsinstrumenten is die een goed beheer van het historisch erfgoed moeten ondersteunen. Vanuit de kennis en de ervaring die inmiddels in het Gentse Prinsenhof werd opgebouwd, lijkt het logisch het hele Prinsenhofareaal te beschouwen als één beheerszone met specifieke beheersvoorschriften die onder meer op het volgende zouden moeten afgestemd zijn: archeologisch en bouwarcheologisch onderzoek voorafgaand aan alle bouwwerken op de percelen die nog niet eerder werden onderzocht, subsidiëring voor het in stand houden van de onderdelen en bouwkundige relicten die nog getuigen van de vroegere Wal of het latere Hof ten Walle, ongeacht of ze vanaf het openbaar domein zichtbaar zijn of niet, en of ze al dan niet wettelijk als monument beschermd zijn, het behoud van de historische littekens in de perceelsstructuur.

\section{De definitieve verkaveling}

Het recente projectonderzoek heeft voorts kunnen uitmaken hoe het hele areaal van het Hof ten Walle zoals het zich sinds de late 14de eeuw als afzonderlijke entiteit binnen de laatmiddeleeuwse stadsfortificatie kon ontplooien, in diverse fasen werd verkaveld en binnen het stadsweefsel werd opgenomen. Een eerste fase werd gerealiseerd in $1649^{91}$ toen het centrale landsbestuur in Brussel de beslissing nam om het voorhof en de bijgebouwen te verkopen. Alleen het kerneiland bleef als vorstelijk bezit behouden en werd grotendeels ter beschikking gesteld van hoge ambtenaren. Voor de verkoop van 1649 maakte meester-landmeter en architect P.C. Mercx een plan op waarop de vierendertig loten ingetekend staan. Op twee na werden die toen te koop aangeboden. Ze werden op 28 juni 1649 toegewezen aan meester-metselaar Pieter de Smet die zeker voor de zuidelijke helft grootse ontwikkelingsplannen had, onder meer met de aanleg van een nieuwe straat ${ }^{92}$. Het project ging evenwel niet door. Met de steun van landvoogd Leopold-Willem verwierven de ongeschoeide karmelieten dit gedeelte op 22 augustus 1651 . In verschillende bouwcampagnes bouwden zij een klooster uit met een classicistische kerk aan de Burgstraat ${ }^{93}$. Het hele gebouwencomplex en de tuinen liggen binnen het areaal van het vroegere Prinsenhof.

91 LIEVOIS, D., 'De privatisering in 1649', in: LALEMAN, M.C. (dir.), $O p$ cit., p. 203-207.

92 Zie onder meer: DE POTTER, F., Second cartulaire de Gand, Gand, s.d., p. 291-294.

93 Zie onder meer: HENRICUS A S. FAMILIA, Geschiedenis van het klooster der karmelieten-Diskalsen te Gent, Gent, 1925; MAES, D., 'De kerk en het klooster van de discalsen of ongeschoeide karmelieten - Burgstraat', in: Ghendtsche Tydinghen, Gent, 1999, jg. 28 nr. 6, p. 354-360. 


\section{HET PRINSELIJK HOF TEN WALLE IN GENT}

Het kerneiland werd pas in 1777 te koop aangeboden ${ }^{94}$. In eerste instantie werd het bod aanvaard van meester-metselaar Adriaen Van de Cappelle (1745$1804)^{95}$. Het gehele bezit werd verder doorverkocht. De noord- en de oostvleugel kwamen in handen van de douairières van Jean Emanuel en Pierre de Loose die er onder meer een zeepziederij en een raffinaderij inrichtten. Het zuidwestelijke deel, met onder meer de zaal en de kapel, kwam in handen van Pierre Vispoel en apotheker Guillaume Goormachtig. De suikerraffinaderij die daar werd opgericht, werd naderhand omgevormd tot een katoenstoomspinnerij. De noordvleugel werd in woningen opgesplitst. Rondom de oostvleugel en aan de zuidkant werden stroken opgevulde gracht en grond van nieuwe woningen voorzien, waarbij vroegere delen van het vorstelijke eigendom betrokken werden. De westsector bleef ondanks zijn hoofdzakelijk nieuwe industriële bestemming, nog enige tijd goed in het stadslandschap herkenbaar, wat onder meer blijkt uit enkele bewaard gebleven iconografische documenten.

Het is merkwaardig vast te stellen hoeveel meester-metselaars er belangstelling hadden voor het Prinsenhofgebied, in het bijzonder voor de vrijgekomen gronden, die zonder enige stedelijke reglementering konden bebouwd en opnieuw verkocht worden, en voor de grote kasteelgebouwen die als uitstekend geschikt werden bevonden voor de ontplooiing van opkomende industriële bedrijvigheden. Ze werden ook door de verkopende overheid als dusdanig aangeprezen om er de interesse voor te vergroten. Pas in een volgende fase gingen de industriëlen nieuwe gebouwen oprichten aan de rand van de stad.

Behalve de reeds vermelde Pieter de Smet in de 17de eeuw was er de belangstelling van Pieter Colpaert (1749-1823), zowat de vaste partner van de familie De Loose bij hun bouwondernemingen in Gent ${ }^{96}$. Zo was hij ook betrokken bij de verkaveling van het penitentenklooster en bij de bouw van huizen voor de familie De Loose in de Burgstraat, de Veldstraat en de Lange Steenstraat. De broers De Loose waren succesvolle handelslui die via een in 1752 opgerichte handelscompagnie en dank zij de financiële inbreng van hun echtgenotes, de zussen Ameloot, in korte tijd een enorm fortuin hadden weten te verzamelen. Na hun dood werden de zeer gediversifieerde handelsactiviteiten door de douairières voortgezet ${ }^{97}$.

94 EVERAERT, G. \& LIEVOIS, D., 'Van hof tot huizenblok', in: LALEMAN, M.C. (dir.), Op cit., p. 209-234. Zie ook: VAN LOKEREN, A., 'La Cour...', p. 45-52; VAN WESEMAEL, M., Op. cit., 1980, p. 274-275.

95 DE VUYST, W., 'Adriaen Van de Cappelle', in: LALEMAN, M.C. (dir.), Op cit., p. 219-244.

96 DE VUYST, W., 'Familie De Loose', in: LALEMAN, M.C. (dir.), Op.cit., p. $219-220$.

97 Zie onder meer: VOISIN, A., Sur l'endroit précis où Charles $V$ est né à Gand, in: Messager des sciences et des arts, Gand, 1825, p.256-262. 


\section{MARIE CHRISTINE LALEMAN}

\section{Toekomst?}

Met deze nieuwe bijdrage wilden we enkele minder bekende aspecten van het vroegere Hof ten Walle of het Gentse Prinsenhof in een ruimer perspectief situeren en de problemen aankaarten waarom het hedendaagse erfgoedbeheer geen afdoend antwoord kan geven op de verwaarlozing, en uiteindelijke teloorgang van dergelijke complexe stedelijke of randstedelijke sites. De verwoorde bevindingen sluiten uiteraard aan bij het interdisciplinaire onderzoeksproject dat in 1998 door de Gentse Vereniging voor Stadsarcheologie werd opgezet. $\mathrm{Na}$ de afsluiting van dat project in 2000, werden nog heel wat aspecten verder uitgediept, onder meer door historicus Daniel Lievois, Dr. René Vermeir en Prof. Dr. Ir. Krista De Jonge. Ook deze bijdrage vormt geen eindpunt. Zoals her en der vermeld worden diverse vraagstellingen verder aangepakt, zoals bijvoorbeeld de 14de-eeuwse verkaveling aan de oostzijde van het Prinsenhof, de gehistorieerde kraagstenen uit de grote zaal, het bouwblok tussen Abrahamstraat en Burgstraat. Hopelijk kan ook dit beknopte overzicht bijdragen tot zowel de wetenschappelijke als de cultuurhistorische betekenis van le Wal bij Gent. 